\title{
Kamulaştırmasız El konulan Taşınmazın İdarenin Mülkiyetine Geçmesinden Sonra Eski Mal Sahibinin Taşınmazına Tekrar
}

\section{Kavuşması}

\section{Atila Erkal ${ }^{*}($ )}

\section{Öz}

Mülkiyet hakkına müdahale kanunun öngördüğü şekillerde kamu yararı amacıyla gerçekleşebilir. Bu amaçla kanunda farklı imkânlar öngörülmüşse de özel mülkiyete tabi taşınmazlar kamulaştırma yoluyla elde edilmektedir. Kamulaştırma Kanunu (KK) eski taşınmaz sahiplerine, taşınmaza ihtiyaç kalmaması durumunda belli şartlar altında iade imkânı ve geri alma hakkı tanımaktadır. İdare özel mülkiyete tabi taşınmazlara, kamulaştırma yapmadan da hukuka aykırı bir şekilde fiili olarak el atabilmektedir. Bunun yanında hukuki olarak el attğı taşınmazları uzun süre mülkiyetine geçirmeden kişilerin mülkiyet hakkını ihlal edebilmektedir.

Kamulaştırmasız el atıldıktan sonra açılan dava neticesinde mahkemece idare adına tesciline karar verilen taşınmazlara ihtiyaç kalmaması, kamu yararı ya da başka bir kamu hizmetine tahsis edilmemesi durumunda, eski maliklerin taşınmazına tekrar kavuşmasını sağlayan, idare tarafindan iade ya da malikin geri alma hakkını düzenleyen bir hüküm bulunmamaktadır. Bu konuda bir hukuk boşluğu mevcuttur. Bu hukuk boşluğu KK'daki hükümlerin kıyas yoluyla uygulanmasıyla giderilebilecektir.

Bir kanun hükmünün kıyasen uygulanması için, uygulanacak olaya ilişkin kanun hükmünün olmaması, olayın benzerlik taşıması ve sonucun aynı olması gerekmektedir. Özel hukukta kural olarak kıyas yoluyla akıl yürütme önünde bir engel bulunmamaktadır. Kamu hukukunun özelliği sebebiyle kıyas belli şartlar altında uygulanabilmektedir. İdare Hukuku’nda ağırıklı olarak hak yaratıcı bazı durumlarda kıyas yapılabilmektedir. KK'nun kamulaştırılan taşınmazın eski malikine iadesine ve malikin geri alma hakkına ilişkin hükümleri, uyuşmazlıkta adli yargı öngörüldüğünden özel hukuk bağlamında kıyasen kamulaştırmasız el atmalar bakımından da uygulanabilir niteliktedir.

\section{Anahtar Kelimeler}

Kamulaştırmasız El Koyma, Fiili El Atma, Hukuki El Atma, Eski Malike İade, Malikin Geri Alma Hakkı

\section{Re-acquisition of the Land by Former Owner After Administrative Authority confiscated the land without expropriating}

\begin{abstract}
Interferences with property rights can only be carried out in the public interest in a manner prescribed by law. Although the law provides different options for this purpose, land that is subject to private property is acquired through expropriation. The Expropriation Act grants former owners the right to return the property under certain conditions and to take it back if the property is not needed. The administration can de facto take possession of privately owned land illegally without expropriation. In addition, it can violate the property rights of individuals without legally taking over the property that it has long confiscated.

As a result of the lawsuit that was filed after the confiscation without expropriation and the court has made a decision to register the property on behalf of the administration and accordingly the administration does not need the property after
\end{abstract}

* Sorumlu Yazar: Atila Erkal (Doç. Dr.), Sakarya Üniversitesi, Hukuk Fakültesi, İdare Hukuku Anabilim Dalı, Sakarya, Türkiye. E-posta: atilaerkal@sakarya.edu.tr ORCID: 0000-0002-7394-5414

Attf: Erkal A, "Kamulaştırmasız El konulan Taşınmazın Idarenin Mülkiyetine Geçmesinden Sonra Eski Mal Sahibinin Taşınmazına Tekrar Kavuşması" (2021) 79(3) İstanbul Hukuk Mecmuası 963. https://doi.org/10.26650/mecmua.2021.79.3.2604 
a while or not for the public benefit or another public service is not regulated by law that the former owner can take back the property from the administration or the right of return of the property. There is a legal loophole in this regard. This legal loophole can be closed by analogy with the provisions of the Expropriation Act.

In order for a legal provision to be applied by analogy, there should be no legal provision regarding the event to be applied, the event should be similar and the result should be the same. As a rule, there is no obstacle to analogous application in private law. Due to the nature of public law, an analogy can be made under certain conditions. There are different views in the areas of constitutional, criminal, tax and administrative law under public law. In administrative law, analogy is mainly carried out in some favorable cases. The provisions of the Expropriation Act on the return of the expropriated property to the previous owner and the owner's right of repossession apply comparatively to hand assignments without expropriation.

\section{Keywords}

Confiscation Without Expropriation, Actual Confiscation, Legal Confiscation, Return to Former Owner, Right of Owner to Take Back

\section{Extended Summary}

The administration needs immovables belonging to private persons in order to perform public services. The right to property is among the rights and duties of the person in article 35 of the Constitution. Expropriation is among the social and economic rights and duties in Article 46 of the Constitution. Since the confiscation of the immovables belonging to private persons by the administration brings a limitation to the property right, it is obligatory to comply with the basic principles of regulation and restriction. The Expropriation Law stipulates the expropriation of privately owned real estates for public benefit and regulates the procedure of legal intervention in detail. In addition, the 18th article of the Zoning Law gives the authority to confiscate up to $45 \%$ of the immovable property free of charge in cases listed in the article.

It is against the law for the administration to take possession of an immovable property without expropriation. In the actual confiscation, it causes an arbitrary behavior without relying on any decision of the administration and without paying the price of the immovable, causing a violation of the property right. In case of actual confiscation, the owner of the immovable property has the right to open lawsuits such as prevention of confiscation, demanding the value of the property, compensation or compensation in return for occupation. However, by making temporary arrangements, the legislator has made legal regulations stating that the ownership of the immovables that are actually confiscated without expropriation will be transferred to the administration and the cost will be paid to the owner of the immovable. These regulations are in the nature of an amnesty against the unlawful act of the administration. In addition to this, as in the zoning plans of a real property, if it does not expropriate or carry out other applications within a period of 5 years, legal confiscation without expropriation is in question. In legal seizure, it is illegal because the administration did not make a zoning program to implement the zoning plans within 5 years, did not take a decision to transfer the property to the administration or expropriated. 
The Expropriation Law allows the former owner to regain his property under certain conditions. According to Article 22 of the Law, if there is no need to allocate the property for the purpose of expropriation or a need for public benefit after the expropriation is finalized, the situation is announced to the former owner in accordance with the provisions of the Notification Law, and to pay the expropriation value of him or his inheritors within three months, together with the legal interest that will accrue from the day they receive the expropriation value. provided that he can take back the immovable. Article 23 of the Law regulates the former owner 's right to take back the immovable. Accordingly, within five years from the date of the expropriation value, the expropriation authority does not carry out any operation or installation suitable for the purpose of expropriation and transfer, or if the immovable property is left as it is, by not allocating it to a need for public benefit, the owner or the heirs shall be legally charged with the expropriation fee from the day they receive the expropriation fee. He can take back the real estate by paying it together with the interest. The former owner must request from the administration to return the immovable to him within one year from the date of his right to take back.

As a result of a legal expropriation, the possibility of the former owner to regain his / her immovable property is foreseen by law, but there is no regulation for the immovables that have been illegally seized, especially after the court has made a registration decision on behalf of the administration. For this reason, there is a legal loophole. This gap can be eliminated by applying the provisions regarding the return of the immovable property to the former owner or the right to take it back in the Expropriation Law by analogy.

While the comparison is free as a rule in private law, it is a controversial issue in public law. On the other hand, freedom of comparison is considered predominantly in terms of beneficial transactions in Administrative Law. However, since Article 24 of the Expropriation Law mandates the judicial judiciary for disputes regarding the return of the relocation to the former owner and the right of the owner to take back, it should be compared within the framework of private law. Benchmark is the application of a provision laid down in the law for a specific event to a similar event not regulated by law. In order to be able to apply for a comparison procedure, there must be a provision in the law on the compared subject, this provision must not be exceptional, there is no provision regarding the compared event, and the compared event must have the same quality in terms of reason and purpose. Since these conditions for comparison are also available in terms of immovables that are actually confiscated without expropriation, there is no obstacle to the application of the aforementioned provisions by comparison. In addition to the Constitution and the ECHR, which protect the property right, it necessitates the strictness in accordance with the principles of justice and equity. As in the case of the administration selling 
the said immovables to someone else, a situation on the contrary will constitute a violation of both the aforementioned regulations and principles, and will lead to the violation of the personal right and fair balance recognized by the property right. Moreover, the failure to recognize the rights of the former owner in the acquisition of property by arbitrarily and unlawfully violating the property right of the former owner in the immovable property, which was transferred to the ownership as a result of the decision of the administration to comply with the law, is incompatible with the Rule of Law. 


\title{
Kamulaştırmasız El konulan Taşınmazın İdarenin Mülkiyetine Geçmesinden Sonra Eski Mal Sahibinin Taşınmazına Tekrar Kavuşması
}

\begin{abstract}
Giriş
İdare, kamu hizmetlerini ifa edebilmek için özel mülkiyette bulunan taşınmazlara ihtiyaç duyabilmektedir. İdarenin ihtiyaç duyduğu taşınmazları hukuka uygun bir şekilde mülkiyetine geçirmesi esastır. Mülkiyet hakkına ilişkin temel esaslar Anayasa'nın 35. maddesinde yer almaktadır. Bunun yanında kamulaştırma yoluyla hukuka uygun müdahale konusunda Anayasa'nın 46. maddesi temel ilkelere yer vermekte ve KK ile bu usul düzenlenmektedir. Kamulaştırmanın temel ögesi kamu yararı olmakla birlikte, bir taşınmaz üzerindeki mülkiyet hakkının, karşılı̆ğ ödenmek kaydıyla malikin rızasına bakılmaksızın idarece kaldırılması ve taşınmazın kendi mülkiyetine geçirilmesidir. ${ }^{1}$ Bunun yanında idare İmar Kanunu'nun 18. maddesi uyarıca kamu hizmetleri için gerekli olan ve maddede sayılan durumlarda düzenleme ortaklık payı olarak özel mülkiyetteki taşınmazlara bedelsiz olarak el atabilmekte ve mülkiyetine geçirebilmektedir. Kanunla öngörülen bu yetkiler dışında özel mülkiyette bulunan taşınmazlara idarenin el koyması hukuka aykırılık teşkil etmektedir. Ancak idarenin bir kamulaştırma kararı olmaksızın, kanunun verdiği bir yetkiye dayanmadan özel mülkiyette yer alan bir taşınmaza el koyması uygulamada karşılaşılan bir durumdur. Kamulaştırmasız el koyma² olarak ifade edilen bu durumda idarenin mevzuat dışına çıkarak keyfi davranması söz konusudur.
\end{abstract}

Kamulaştırmasız el koymada taşınmaz, idarenin mülkiyetine geçmemekte, ancak idare söz konusu taşınmaza fiili ya da hukuki olarak el atmaktadır. Mülkiyet hakkı hukuka aykırı bir şekilde sınırlandırılan taşınmaz sahibi buna karşı yargı yoluna başvurma hakkına sahiptir. Fiili el atmada malik müdahalenin men'ini talep edebileceği gibi ecrimisil, bedel veya tazminat talep ederek idare adına tescilini de isteyebilmektedir. Buna karşılık kanun koyucu belli dönemlerde kamulaştırmasız fiili el atılan taşınmaz sahibine sadece bedel ve tazminat talep etme hakkı tanıyarak mülkiyetin idareye geçeceğini düzenlemiştir. Kamulaştırmasız el konulan taşınmazların gerek malik tarafından mahkemeden idare adına tescilinin istenmesi, gerekse kanun koyucunun bu yönde bir kural getirmesi sebebiyle idarenin mülkiyetine geçen taşınmazların ihtiyaç kalmaması durumunda akıbeti konusunda bir hüküm bulunmamaktadır. Benzer durum hukuki el atmalarda da ortaya çıkmaktadır. İdarenin zamanla taşınmaza ihtiyacının kalmaması sebebiyle malike iade yetkisi ya da malikin geri alma hakkı olup olmadığı tartışmalı bir konudur. Buna karşılık hukuka uygun bir kamulaştırma işleminde, KK'ndaki şartlar gerçekleşmişse, malikin kamulaştırılan

Anayasa Mahkemesi, 2003/33, 10.04.2003; Halil Kalabalık, Imar Hukuku Dersleri, (9. Bas1, Seçkin 2019) 276.

Kamulaştırmasız el koyma yerine "kamulaştırmasız el atma", "fiili el atma" ayrımı yapılarak "dolayısıyla el koyma" ya da "de facto kamulaştırma" kavramları da kullanılmaktadır. Bu çalışmada yeri geldikçe el koyma ve el atma kavramları birlikte kullanılacaktır. 
taşınmazı geri alma hakkı bulunmaktadır. Ayrıca idarenin kamulaştırdığı taşınmaza ihtiyacı kalmamışsa, eski malike iade yetkisi de mevcuttur.

$\mathrm{Bu}$ çalışmada kamulaştırmasız fiili ve hukuki el atma üzerine mahkemece idare adına tescil kararı ${ }^{3}$ verilen taşınmaza, ihtiyaç kalmaması üzerine eski mal sahibine iadesi ve malikin geri alma hakkının bulunup bulunmadığı sorunu incelenecektir. Öncelikle mülkiyet hakkı bağlamında kamulaştırma ve kamulaştırmasız el atma kavramlarına yer verilerek mülkiyetin idareye geçme süreci ele alınacaktır. Daha sonra mal sahibinin geri alma hakkı ya da idarenin ihtiyacı kalmayan taşınmazı mal sahibine iade yetkisi olup olmadığı, mevcut hükümlerin kıyasen uygulanıp uygulanamayacă̆ irdelenecektir.

\section{Kamulaştırmasız Eı Koyma Kavramı}

Kamulaştırmasız fiili el koyma kavramı ${ }^{4}$ yargısal içtihatların yanında doktrin tarafından da tanımlanmaktadır. Buna karşılık açık bir kanuni tanımı bulunmamakla birlikte, KK'nun Geçici 6. maddesinde lafzen geçmese de, kamulaştırmasız fiili el koymayı dolaylı tanımladığını kabul edebiliriz. ${ }^{5}$ Kamulaştırmasız hukuki el atma ise KK Ek 1. madde ile kanuni bir zemine kavuşmuştur. Kavramsal olarak kamulaştırmasız el koymayı ele almadan önce mülkiyet hakkı karşısındaki durumunu incelemekte fayda bulunmaktadır.

\section{A. Kamulaştırmasız Eı Koyma ve Mülkiyet Hakkı}

Hukuk devletinde kişilere tanınan önemli temel haklar arasında yer alan mülkiyet hakkı, anayasal güvence altındadır. Anayasa'nın 35. maddesinde, herkesin mülkiyet hakkına sahip olduğu ve bu hakka ancak kamu yararı amacıyla, kanunla sınırlandırma getirilebileceği hüküm altına alınmıştır. AİHS Ek 1 nolu Protokolün 1. maddesine göre de, mülkiyet hakkına kamu yararı amacıyla ancak kanunla ve uluslararası hukukun genel ilkelerine göre müdahale edilebilir. ${ }^{6}$

Mülkiyet hakkının Anayasa’ da kişi hak ve ödevleri içerisinde yer alması sebebiyle Cumhurbaşkanlığı Kararnamesi ya da başka bir düzenleyici işlemle sınırlandırılması

\footnotetext{
Hukuki el atmada farklı bir süreç işlemektedir. Bunun için bkz III.B. Kamulaştırmasız El Atmada Mülkiyetin İdareye Geçmesini Sağlayan Durumlar başlı̆̆1.

4 Kamulaştırma kavramı yerine "dolayısıyla kamulaştırma” kavramının tercih edilmesi yönünde yaklaşımlar bulunmaktadır. Bkz Fatma Ayhan, 'Kamulaştırma Kanunu'nun Geçici 6. Maddesi ve Türk Hukukunda "Dolayısıyla Kamulaştırma" Uygulaması Üzerine Bir Deneme' (2011) 69 (1-2) IÜHFM 1125, 1127.

5 Danıştay 6 D, 2014/4122, 27.05.2014, (Legalbank); Aksi yönde bkz Türker Yalçınduran, ‘6745 Sayılı Kanun İle Hukuki El Koymalara Dair Yapılan Değişiklikler İle Hukuki Ve Fiili El Koymalara Uygulanacak Hükümler’ (2017), 66 (2), AÜHFD 491, 500.

6 Mülkiyet hakkına ilişkin AİHM karar örnekleri için bkz Oğuz Sancakdar, 'AİHM'in Gayrımenkul Mülkiyeti ve İmar Hukuku Uyuşmazlıklarına Yaklaşımından Kesitler Ve Karar Örnekleri’ İzmir BD (2019), 84 (3) 511, 512 ff.
} 
mümkün değildir. ${ }^{7}$ Mülkiyet hakkına el atma yetkisini düzenleyen kanunun Anayasa'nın temel hak ve hürriyetlerin sınırlandırılmasına ilişkin 13. maddesinde yer alan temel yükümlülükleri de içermesi bir zorunluluktur. Buna göre ilgili kanun mülkiyet hakkını, özüne dokunmaksızın yalnızca Anayasa'nın ilgili maddelerinde belirtilen sebeplere bağlı olarak sınırlandırabilir. Bu sınırlama Anayasa'nın sözüne ve ruhuna, demokratik toplum düzenine ve lâik Cumhuriyetin gereklerine ve ölçülülük ilkesine aykırı olmamalıdır. Ayrıca genel nitelikte olmalı, güvenin korunması ve eşitlik ilkesine uygun olmalıdır. ${ }^{8}$

Anayasa'nın 46. maddesi kamulaştırmayı özel olarak hüküm altına alarak mülkiyet hakkını sınırlandırmaktadır. Sosyal ve ekonomik haklar ve ödevler arasında yer alan kamulaştırmayla ${ }^{9}$; Kamu yararının gerektirdiği hallerde, gerçek karşılıklarını peşin ödemek şartıyla, özel mülkiyette bulunan taşınmaz mallara kanunla gösterilen esas ve usullere göre hukuka uygun el atılabileceği belirtilmektedir. ${ }^{10}$ Her ikisi de Anayasa'da düzenlenmekle birlikte, mülkiyet hakk1 1961 Anayasa'sında ${ }^{11}$ sosyal ve iktisadi haklar ve ödevler başlığı altında düzenlenirken, 1982 Anayasası'yla kişi hak ve ödevleri kapsamına alınmıştır. ${ }^{12} \mathrm{Bu}$ değişiklikle birlikte ve Anayasa'nın 46. maddesinin mevcut haliyle mülkiyet hakkının daha güçlü bir konuma geldiği aşikardır. $^{13}$

Kamulaştırmaya ilişkin esas ve usuller ise 2942 sayılı Kamulaştırma Kanunu ile belirlenmiş ve hukuka uygun el atma süreci ayrıntılı bir şekilde düzenlenmiştir. Ancak Kanunun Geçici 6. maddesi bunun dışına çıkarak, kamulaştırmasız el atma

Anayasa'nın 104. maddesine göre Cumhurbaşkanlığı Kararnameleri ile temel hak ve ödevler alanında sadece sosyal ve ekonomik hak ve ödevleri düzenlenebilir. Kişi hak ve ödevleri ile siyasi hak ve ödevler düzenlenemez. Kamulaştırma her ne kadar sosyal ve ekonomik hak ve ödevler arasında yer alsa da kanunla gösterilen usul ve esaslara göre yapılacağ 1 açıkça düzenlendiğinden, Anayasanın 104/17. fikrasına göre Cumhurbaşkanlığı Kararnamesi ile düzenlenemez. Bu konuda münhasıran kanunla düzenleme yapılabilir. Anayasa Mahkemesine göre Anayasa koyucunun bir konunun kanunla düzenlemesini özel olarak öngörmesi bu alanın münhasıran kanunla düzenlemesini istediği anlamına gelir. Anayasa'da kanunla düzenleneceği belirtilen alanlarda CBK çıkarma yetkisi bulunmamaktadır. Anayasa Mahkemesi, 2020/5, 23.01.2020; Anayasa Mahkemesi, 2020/4, 22.01.2020.

8 Hartmut Maurer, Allgemeines Verwaltungsrecht (14. Bası, C.H. Beck 2004) 710.

9 Karşılaş̧ırmalı hukukta Almanya örneğine baktığımızda kamulaştırma Alman Anayasası'nın 14. maddesinde mülkiyet hakkıyla birlikte düzenlenmektedir. Maddenin ilk iki fikrası mülkiyet hakkını 1982 Anayasası'nın 35. maddesine benzer bir şekilde düzenlerken 3. fikrası kamulaştırmayı hüküm altına almaktadır.

10 İdare kendisine Anayasa tarafından tanınan olanak ve yetkileri Yasa'ya uygun bir biçimde kullanmaksızın taşınmaza el atarak kamulaştırma ilkelerine aykırı davranamaz. Anayasa'nın sınırlarını belirleyerek izin verdiği kamulaştırma yöntemini kullanmadan yapılan el atmalar anayasal dayanağı olmayan kamulaştırmasız el koymadır ve mülkiyet hakkına müdahaledir. Anayasa Mahkemesi, 2003/33, 10.04.2003; Hukuk sisteminde öngörülen usuller dışında kamulaştırma yapmaksızın ve taşınmaz bedeli ödenmeksizin el atılması mülkiyet hakkını ihlal eder. Anayasa Mahkemesi, İkinci Bölüm, Emel Kaynar ve Diğerleri kararı, B. no: 2013/3667, 10.06.2015; Papamichalopoulos v Greece App no 14556/89 (ECHR 24 Juny 1993); Carbonara and Ventura v Italy, App no 24638/94 (ECHR 2000- VI) ve Belvedere Alberghiera S R. L. Italy, App no 31524/96 (ECHR 30 May 2003).

11 Türkiye Cumhuriyeti Anayasas1, Kanun Numarası: 334, Kabul Tarihi: 09.07.1961, RG 20.07.1961/10859.

121961 Anayasası'nın 36. maddesinde yer alan mülkiyet hakkına ilişkin hüküm aynen korunarak 1982 Anayasası'nda kişi hak ve hürriyetleri kapsamına alınmıştır. Meltem Kutlu Gürsel, Kamulaştırma Hukuku (3. Bası, Seçkin 2019) 36 ff.

13 Necmi Yüzbaşığlu, '2001 Anayasa Değişiklikleri Üzerinde Bir Değerlendirme’ Yıldızhan Yaylaya Armağan (Galatasaray Üniversitesi Yayınları no: 4, 2003) 587, 594; Kutlu Gürsel (n12) 40. 
kavramını kanuni bir zemine taşımıştır. ${ }^{14}$ Kamulaştırmasız el atma, kamulaştırma mahiyetinde olmadığı için Anayasa'nın 46. maddesi değil, 35. maddesi bağlamında mülkiyet hakkına müdahale kapsamındadır. ${ }^{15}$

Kamu hizmetinin ifasında kamu yararı ile bireysel hak ve menfaatler çatıştığı durumda kamu yararı önce gelmektedir. Taşınmaz malikleri hukuka uygun kamulaştırmalara kamu yararı uyarınca katlanmak zorundadır. Buna karşılık devlet, kamu yararı sebebiyle hakları ve menfaatlerinden fedakârlık yapmaya zorlanan, hak kaybına uğrayan kişilerin zararını ödemekle yükümlüdür. ${ }^{16}$ Hukuka aykırı müdahalelere karşı ise taşınmaz sahipleri kendisini savunabilmelidir. ${ }^{17}$ KK Geçici 6. maddesinin yukarıda ifade ettiğimiz mülkiyet hakkına hukuka uygun müdahaleyi düzenleyen anayasal hükümlerle uyum içinde olduğunu söylemek güçtür. Söz konusu madde idare tarafindan belli yıllar arasında el konulmuş özel mülkiyette yer alan taşınmazların bedelinin ödenerek idarenin mülkiyetine geçmesini öngörmektedir. ${ }^{18} \mathrm{Bu}$ hükümle birlikte taşınmaz mal sahiplerine sadece bedel talep etme hakkı tanınmış, mülkiyet hakkından kaynaklanan diğer hakları kısıtlanmıştır. ${ }^{19}$ Sadece bedel talep hakkı tanıyıp, diğer hakları için yargıya müracaat hakkı sınırlandırılarak Anayasa’nın 36. maddesinde güvence altına alınmış hak arama özürlüğü ve bu bağlamda adil yargılanma hakkının ihlal edildiği söylenebilir. Anayasa Mahkemesi hak arama özgürlügünün kapsamını belirlerken, herkesin yargı

14 Geçmişte de benzer düzenlemeler yapılmıştır. 221 sayılı Amme Hükmi Şahıslar veya Müesseseleri Tarafından Fiilen Amme Hizmetine Tahsis Edilmiş Gayrimenkuller Hakkındaki Kanunun 1. Maddesine göre "6830 sayılı İstimlâk Kanununun yürürlüğe girdiği tarihe kadar, kamulaştırma işlerine dayanmaksızın, kamulaştırma kanunlarının göz önünde tuttuğu maksatlara fiilen tahsis edilmiş olan gayrimenkuller ilgili âmme hükmi şahsı veya müessesi adına tahsis tarihinde kamulaştırılmış sayılır." Geçmişteki kanuni düzenlemelerin tarihi seyri için bkz. Sadullah Özel, 'Anayasa Mahkemesi ve Kamulaştırmasız El Atmanın Yasallaştırılması Girişimleri’ (2015) 13 (154) LHD 61, 68 ff.; Ayhan (n 4) 1135.

15 Hans Dieter Jarass ve Bodo Pieroth, Grundesetz für die Bundesrepublick Deutschland, Kommentar, (5. Bası, C.H. Beck 2000) 376 .

16 Maurer (n 8) 699; Kamulaştırma yoluyla mülkiyet hakkına el atılması karşılığında bedel ödenmesi konusunda ilk pozitif düzenleme 18. YY. da "Prusya Devletleri Genel Memleket Hukuku” (Allgemeines Landsrecht für Preußischen Staaten- ALR) isimli kanun kodifikasyonunun 74 ve 75. maddelerinde yer verilmiştir. Bu hükümler sadece kamulaştırmayı kapsamamakta, kamu yararı ile bireysel hak ve menfaatler çatıștı̆̆ durumda kamu yararının önce geleceğini düzenlemektedir. Bireyler haklarının kısıtlanmasına katlanmak zorundadır, buna karşılık devlet, kamu yararı sebebiyle hakları ve menfaatlerinden fedakârlık yapmaya zorlanan, hak kaybına uğrayan kişilerin zararını ödemekle yükümlüdür. Bu hükümler birçok hukuk sistemini etkilemiş ve günümüzde de geçerli olan fedakârlığın denkleştirilmesi ilkesini ortaya çıkarmıştır.

17 Maurer (n 8) 707 .

18221 sayılı Kanun 9.10.1956 tarihinden önceki kamulaştırmasız el atılan taşınmazlarda, 2 yıllık bedel talep hakkı tanıdığından ve bu süreyi hak düşürücü olarak öngördügünden, sürenin kaçırılması durumunda bedel talep hakk1 sona ermiştir. Ali Çuvalcı, Kamulaştırma Kanunundan Doğan Bedel Ve Tescil Davaları (1. Bası, Seçkin 2019) 671.

19 Anayasa Mahkemesi, KK'nun 38. maddesinde yer alan; “Kamulaştırma yapılmış, ancak işlemleri tamamlanmamış veya kamulaștırma hiç yapılmamış iken kamu hizmetine ayrılarak veya kamu yararına yönelik bir ihtiyaca tahsis edilerek üzerinde tesis yapılan taşınmaz malın malik, zilyed veya mirasçılarının bu taşınmaz mal ile ilgili her türlü dava hakk yirmi yll geçmekle düşer. Bu süre taşınmaz mala elkoyma tarihinden başlar.” hükmünü Anayasa'nın 2., 13., 35. ve 46. maddelerine aykırı bularak iptal etmiştir. Gerekçesinde kamulaştırmasız el atılan bir taşınmazın malik, zilyed veya mirasçılarının el atmanın önlenmesi, taşınmazın karşılığı olan bedelinin istenmesi, tazminat veya işgal karşılığı tazminat davası gibi davaları açmaktan men edilemeyecekleri; Temel hak ve özgürlükleri büyük ölçüde kısıtlayan veya kullanılamaz hale getiren sınırlamaların hakkın özüne dokunacağını, temel hak ve özgürlüklere getirilen sınırlamaların yalnız ölçüsü değil, koşulları, nedeni, yöntemi, kısıtlamaya karşı öngörülen kanun yollarının demokratik toplum düzeni kavramı içinde değerlendirileceğini; Devletin veya bir kamu tüzel kişisinin kamulaştırma işlemi olmaksızın temel insan haklarından olan mülkiyet hakkına keyfi bir șekilde el konularak bireylerin sahip oldukları taşınmazları üzerinde özgürce tasarruf etmelerinin engellenmesi ve yirmi yıl sonunda dava hakkı da tanınmayarak, mülkiyet haklarının ellerinden alınması hukuk devleti ilkesine aykırı olduğunu belirtmiştir. Anayasa Mahkemesi, K. 2003/33, 10.04.2003; Hukuki el atmayla malikin kişisel tasarrufta bulunma, rayiç değer üzerinden satma, kiralama, değişiklik yapma gibi mülkiyet hakları kısıtlanmaktadır. Yargitay HGK, 2010/651, 15.12.2010 (Legalbank). 
mercileri önünde davacı veya davalı olarak iddiada bulunma ve savunma hakkına sahip olduğunu ${ }^{20}$ mahkemeye erişim hakkının Anayasa'nın 36. maddesi ve AİHS'in 6. maddesinde güvence altına alındığını ifade etmektedir. ${ }^{21}$ Mahkemeye erişim hakk1 bir uyuşmazlığı mahkeme önüne taşıyabilmenin yanında etkili bir şekilde karara bağlanmasını isteme anlamına da gelmektedir. ${ }^{22}$ Kamulaştırmasız fiili el atmada sadece bedel talep hakkının tanınması mahkemeye erişim hakkının güvence altına alındığı anlamına gelmez. Hak sahibinin mülkiyet hakkından kaynaklanan tüm dava haklarının tanınmasıyla sağlanabilir. Bunun yanında, örneğin müdahalenin men'ini talep edemediğinden, etkili bir şekilde karara bağlamayı isteme hakkının sağlandığını da söylemek güçtür. Yine Anayasa Mahkemesine göre hak arama özgürlüğü, bir temel hak olmasının yanında diğer temel hak ve özgürlüklerden gereken şekilde yararlanmasını ve bunların korunmasını sağlayan en etkili güvencelerden biridir. Davanın bir mahkeme tarafından görülebilmesi, kişiye iddialarını ortaya koyma imkânının tanınması gerekir. ${ }^{23}$ KK Geçici 6. madde uyarınca taşınmaz sahibi müdahalenin men'ini talep edemeyeceğinden, el atmanın hukuka aykırılığını taşınmazın değerine ilişkin bedel tespiti özelinde yapabilecektir. Dolayısıyla iddialarını sınırlı bir şekilde ortaya koyma imkânına sahiptir. ${ }^{24}$ İdarenin kamulaştırmasız el atma yerine, kamulaştırma yaparak zaten taşınmazın mülkiyetini elde etme yetkisinin olduğu, dolayısıyla kamulaştırmasız el atma sebebiyle mülkiyetin idareye geçmesi arasında bir fark bulunmadığı yaklaşımı hukuk devleti ilkesi ile bağdaşmaz. Bu durumda niçin hukukun öngördüğü kamulaştırma yapılmadı sorusu akla gelir. İdare açısından mali kaygılar onun haklılığı sonucunu doğurmaz. ${ }^{25}$ Kamulaştırmasız el atılan taşınmazların mülkiyetinin idareye geçmesini düzenleyen hükümlerin en azından el atma gerekçesi için ileri sürülen kamu hizmeti ve kamu yararının hala devam edip etmediği, el atma için bir zorunluluğun olup olmadığı, diğer temel ilkeler yanında ölçülülük ilkesine uyulup uyulmadığına yargısal denetim imkânı verilmesi gerekir. Maddenin uygulanmasının öngörüldüğü süreler dışındaki kamulaştırmasız fiili el atmalardan farklı olarak, söz konusu hususların varlığı esnetilerek, müdahalenin men'inin de talep edilmesine imkân tanınması, kamu yararında adil dengenin oluşup oluşmadığının tespitine yardımcı olacaktır.

20 Anayasa Mahkemesi, Aladdin Özdemir kararı, B. No: 2018/36426, 21.10.2020, para 22.

21 Anayasa Mahkemesi, Özbakım Özel Sağlık Hiz. İnş. Tur. San. ve Tic. Ltd. Şti. kararı, B. No: 2014/13156, 20.4.2017, para 34.

22 Anayasa Mahkemesi, Özkan Şen kararı, B. No: 2012/791, 07.11.2013, para 52.

23 Anayasa Mahkemesi, Mohammed Aynosah kararı, B. No: 2013/8896, 23.2.2016, para 33.

24 Mülkiyetin maddi değeri yanında manevi değeri de bulunmaktadır. Örneğin bir kişinin çocukluğunu hatta tüm ömrünü geçirdiği anılarıyla dolu bir evin ya da atalarından miras kalan taşınmazın kamulaştırılmasında dahi psikolojik ve manevi değere önem atfedilerek mülkiyet hakkına en ağır müdahale olarak görülürken, idarenin keyfi olarak kamulaştırmasız el atma sebebiyle müdahalenin hukuka aykırılı̆̆ını ileri sürerek müdahalenin menini talep edememek mülkiyet hakkının daha ağır ihlaline neden olacaktır. Buna ilişkin tarihi örnek bir olay için bkz. Yunus Emre Yılmazoğlu ve Duman Özgür, 'Acele Kamulaştırmanın Mülkiyet Hakkı Bakımından Yol Açtı̆̆ı Meseleler: Anayasa Mahkemesi'nin "Ali Ekber Akyol Ve Diğerleri” İle “Ali Hıdır Akyol Ve Diğerleri” Kararlarının Analizi' (2018) 6 (11) UMD 513, 514 ff.

255999 sayılı Kanunla getirilen Geçici 6. maddenin gerekçesinde, kamulaştırmasız el koyma sebebiyle açılacak davalar sebebiyle idareleri mali açıdan zora sokabilecek tazminatlardan korumanın amaçlandığı görülmektedir. Gerekçe için bkz. Mehmet Ali Gölcüklü, Kamulaştırma Kanunu Şerhi: Fiili Ve Hukuki El Atma Davaları (2. Bası, Seçkin 2018) 1159. 
Anayasa Mahkemesi bireysel başvurularda hak arama özürlüğünü haklı olarak kapsamlı bir şekilde ele alırken, kamulaştırmasız el koymaya ilişkin maddenin iptali için açılan davada kısmen iptal kararı vermiş, kamulaştırmasız fiili el koymaya ilişkin kanunla öngörülen hükmü Anayasa’ya aykırı bulmamıştır. Ancak Mahkeme malik aleyhine olan hükümlerin "sürekli" uygulanmasının Anayasa'nın 35 ve 46. maddelerine aykırılık oluşturduğunu ifade etmektedir. ${ }^{26}$ Mahkeme söz konusu kararıyla fiili olarak el atılan taşınmazların kamu hizmetine özgülenmesi sebebiyle, mülkiyetin idareye geçmemesi durumunda kamu hizmetlerinin aksayabileceği yaklaşımı sergileyerek mülkiyetin idareye geçirilmesine cevaz vermiştir. Ancak bu uygulamanın istisnai olması, kanunla tekerrür etmemesi gerektiğinin altını çizmiştir.

Maddenin Anayasaya aykırılığ 1 sorunu bir tarafa kanun koyucu bu madde ile, idarenin hukuka aykırı keyfi davranışına yetki vermeye ve bunu meşrulaştırmaya yönelik bir kanuni düzenleme yapmamıştır. Kanun koyucu bir taraftan fiilen el atılan taşınmazların kamu hizmetinde kullanılması, diğer taraftan taşınmaz sahiplerinin mülkiyet hakkının ihlal edilmesi sebebiyle ortaya çıkan uyuşmazlıklara bir çözüm getirmek amacıyla geçici bir düzenleme yapmıştır. Bu tür hükümlerin sürekli düzenlenmesi ya da sürekli uygulanır hale gelmesi fiili el atmanın olağan hale gelmesi, idarenin böyle bir hükmün çıkmasına yönelik kanısı da kötüye kullanma tehlikesini beraberinde getirir. ${ }^{27}$ Ayrıca Anayasa Mahkemesi Geçici 6. maddenin yürürlük tarihinden itibaren 15 yıl ileriye yönelik olarak kamulaştırmasız el atmalara da uygulanacağına ilişkin hükmü iptal etmiştir. ${ }^{28}$ Dolayısıyla ileriki bir tarihte kanun koyucunun kamulaştırmasız el atılan taşınmazların idarenin mülkiyetine geçeceğine ilişkin getireceği bir hüküm, geçmişteki el atmalara uygulanacaktır. Bu da Anayaysa Mahkemesi’nin 15 yıl ileriye yönelik Anayasa ile güvenceye alınan hakların ihlal edileceğine ilişkin kararının, tersinden geriye yönelik ihlal edileceği anlamına gelecektir. Bu, Anayasa Mahkemesinin yukarıdaki iptal kararı ile çelişir, kararının hükümsüz kalması sonucunu doğurur.

Türk Hukuku’nda kamulaştırmasız fiili el atma sebebiyle getirilen düzenlemeler; kanun koyucunun belirlediği süreler için Fransız Hukuku’ndaki dolaylı kamulaştırma teorisinden de farklı olarak konu sınırlaması olmaksızın geçmişe yönelik dolaylı

26 Anayasa Mahkemesi, 2012/169, 01.11.2012; Anayasa Mahkemesi, 2018/111, 20.12.2018.

$27 \mathrm{Bu}$ düzenlemelerin de idareyi taşınmazlara hukuka aykırı el atmayı teşvik etmeyecek kapsamda olması gerekmektedir. Anayasa Mahkemesi, 2018/111, 20.12.2018; Hatta doktrinde kamulaştırmasız el atma kavramının hukuk devletinde olmaması gerektiği belirtilmektedir. Yalçınduran (n 5) 491, 493; KK'ndan kaynaklanan bedel tespiti ve tescil davalarının yıllara göre istatistiki bilgileri için bkz. Çuvalcı (18) 5. Bunların hatırı sayılı bir kısmı kamulaştırmasız el atma davalarıdır.

28 Bu hüküm, Anayasa Mahkemesi tarafindan malik aleyhine hükümlerin geleceğe yönelik uygulanması halinde kamulaştırma için Anayasa ve Kanun'da bütün güvenceler etkisiz kalabileceği, ileriye yönelik bir uygulamanın özel mülkiyete kamulaştırmasız el atma yoluyla müdahalelerin yol açabileceği, kamulaştırma yerine hukuka aykırı olarak taşınmaza el atma yoluna gideceği gerekçeleriyle iptal edilmiştir. Anayasa Mahkemesi, 2012/169, 01.11.2012. 
kamulaştırmayı kabul eder niteliktedir. ${ }^{29}$ Öngörülen çözüm olan mülkiyetin idareye devri, bedelinin ise taşınmaz malikine ödenmesi, idare lehine malik aleyhine getirilen hükümlerdir. Burada üzerinde durulması gereken diğer bir husus ise, kanun koyucunun geçici de olsa mülkiyet hakkına ilişkin kamu yararı ve adil dengeyi bozan idare lehine, malik aleyhine bu tür düzenlemelerin hukuk devleti ile hangi ölçüde uyuşabildiğidir. Yukarıda maddenin Anayasaya uygunluğu konusundaki çekincelerimiz ifade edilmiştir. Ayrıca KK Geçici 6. maddenin lafzının da sorunlu olduğunu ifade edebiliriz. Kanun koyucu KK Geçici 6. maddede belirtildiği üzere bu tür hükümleri elbette kamu yararını dikkate alarak kabul etmektedir. İdare tarafindan kamulaştırmasız el atılan ve fiilen kamu hizmetlerinde kullanılan taşınmazlarda kamu yararının $^{30}$, bireysel yarardan daha ağır bastığı iddia edilebilir. Ancak taşınmazın elde ediliş şekli kural olarak dokunulamaz kişi hakkı olan mülkiyet hakkının ihlal edilmesi sebebiyle hukuka aykırıdır. Dolayısıyla acil bir kamu hizmeti için dahi olsa idarenin taşınmaza hukuka aykırı el atmasında bireysel yarar karşısında kamu yararını üstün duruma getiremez. Çünkü idarenin hukuka aykırı (haksız fiil), eylem ya da işlemiyle kamu düzeni ihlal edilmektedir. ${ }^{31}$ Kamu düzeni ihlal edilerek kamu yararı gerçekleşemez. Kaldı ki acil durumlar için idareye acele kamulaştırma yetkisi tanınmaktadır. ${ }^{32}$ Dolayısıyla idarenin kamu yararı gerekçesi taşınmaza hukuka aykırı el koymalar için haklı bir mazeret tanımaz. ${ }^{33} \mathrm{Bu}$ nedenle kanun koyucu tarafından getirilen geçici hükümler, idarenin taşınmaza hukuka aykırı kamulaştırmasız fiili el atmasına meşruluk kazandırmaya yönelik değil, idareyi affetmeye yöneliktir. ${ }^{34}$ İdarenin kamulaştırmasız fiili el attığı taşınmazları şeklen de olsa hukuki bir hale getirmeyi amaçlamaktadır. ${ }^{35}$

\section{B. Kamulaştırmasız El Koyma Durumları}

Mülkiyet hakkına hukuka aykırı el koyma, fiili ve hukuki el koyma olmak üzere iki şekilde gerçekleşmektedir. Kamulaştırmasız el atmanın fiili ya da hukuki el koyma olarak nitelendirilmesi görevli yargı kolu ve uygulanacak hukuk kuralları açısından önem taşımaktadır. Fiili el koymaya ilişkin davalar adli yargının görevine girmekte ve özel hukuk kuralları uygulanmaktadır. Buna karşılık hukuki el atma davaları idari

29 Dolaylı kamulaştırma bayındırlık eserlerinin inşası nedeniyle kamulaştırmasız el atmalar için kabul edilen bir Fransız teorisidir. Buna göre kamulaştırmasız el konulan taşınmaz üzerine bayındırlık eseri inşa edilmişse, taşınmaz idarenin mülkiyetine geçmeli taşınmaz sahibi men-i müdahale davası açamamalı, sadece malın bedeli istenebilmelidir. Bkz. Kemal Gözler, İdare Hukuku, C.2 (3. Bası, Ekin 2019) 1017.

30 Kamu yararı için bkz. Cemil Kaya, Kararlarından Hareketle Kamu Yararı Kavramına Danıştay'ın Bakışı, (1. Bası, On İki Levha Yayınları 2011).

31 A. Şeref Gözübüyük ve Turgut Tan, İdare Hukuku, C. 2, İdari Yargllama Hukuku (2. Bası, Turhan 2006) 307.

32 Ayrıntılı olarak bkz Cenk Şahin, Acele Kamulaştırma (1. Bası, XII Levha 2018).

33 Yargitay HGK, 2010/651, 15.12.2010 (Legalbank).

34 Gürsel Kaplan, 'Yeni Yasal Düzenlemelere Göre Kamulaştırmasız El Koyma Sebebiyle Doğan Tazmin Hakkının Tabi Olduğu Usul Ve Esaslar' 2012 (99) TBBD 125, 144.

35 Yoklukla sakat olan kamulaştırmasız el atma müdahaleleri sonradan yasal bir düzenlemeyle meşruiyet kazandığı anlamına gelmemekte sadece şekli anlamda legalize edilmektedir. Özel (n 14) 68. 
yargının görevine girmekte ve idare hukuku kuralları tatbik edilmektedir. ${ }^{36}$ Ayrıca İmar Kanunu'nun 18. madde uyarınca taşınmaza \%45'e kadar düzenleme ortaklık payı olarak bedelsiz el koyma hukuka uygun kamulaştırmasız el atma olarak ifade edilmektedir. ${ }^{37}$ Konu itibarıyla sadece hukuka aykırı el koymalar ele alınacaktır.

\section{Fiili El Koyma}

Fiili el koyma konusunda mevzuatta açık bir tanım bulunmamaktadır. KK'nun tanımlar başlığını taşıyan 2. maddesinde kamulaştırmasız fiili el atma kavramına yer verilmemektedir. Ancak KK Geçici 6. maddesinin, dolaylı bir tanım yaptığını kabul edebiliriz. ${ }^{38}$ Buna göre; "Kamulaştırma işlemleri tamamlanmamış veya kamulaştırması hiç yapılmamış olmasına rağmen 9/10/1956 tarihi ile 4/11/1983 tarihi arasında fiilen kamu hizmetine ayrlan veya kamu yararına ilişkin bir ihtiyaca tahsis edilerek üzerinde tesis yapılan taşınmazlara veya kaynaklara kısmen veya tamamen veyahut irtifak hakkı tesis etmek suretiyle malikin rıası olmaksızın fiili olarak el konulması sebebiyle, mülkiyet hakkından doğan talepler, bedel talep edilmesi hâlinde bedel tespiti ve diğer işlemler bu madde hükümlerine göre yapılır’. Hükmün içeriği ve kullanılan kavramlarla ile ilgili eleştirilecek tarafları bulunmaktadır. Örneğin tahsis etme ve irtifak hakkı kurulması gibi. İrtifak hakkı MK ve KK' da düzenlenmiş, meşru bir yetki veya hakka dayanan hukuki bir kavramdır. Hukuka aykırı kamulaştırmasız el atmada nasıl bir meşru hakkın kurulacağı ya da idarenin mülkiyetine geçmemiş bir taşınmazın kamu hizmetine nasıl tahsis edileceği merak konusudur. ${ }^{39}$

Yargıtay kamulaştırmasız fiili el koymayı "9 Ekim 1956 gününden sonra kamulaştırma işlemi yapılmaksızın ve bir kanun hükmüne dayanılmadan idarenin taşınmaz malüzerindefiilen tasarrufabaşlaması ve asıl mal sahibinin kullanma hakkına engel olması veya bu hakkı ortadan kaldırmış bulunması" olarak tanımlamaktadır. ${ }^{40}$ 221 sayılı Kanun ile 9 Ekim 1956 tarihinden önce kamulaştırmasız fiilen el konulan taşınmazlar kamulaştırılmış sayıldığından, kamulaştırmasız el atmalar bu tarihten sonra söz konusu olmaktadır. ${ }^{41}$ Yargitay bu tarihi milat olarak kabul etmekte ve yukarıda ifade edildiği üzere kamulaştırmasız fiili el atma tanımını bunu göz önünde bulundurarak yapmaktadır. Yargıtay 221 sayılı Kanun öncesinde kamulaştırmasız

36 Uyuşmazlık Mahkemesi, 2012/63, 09.4.2012; Uyuşmazlık Mahkemesi, 2019/814, 23.12.2019; Anayasa Mahkemesi 2013/101, 25.9.2013; Danıştay 6 D, 1990/295, 08.9.1990 (Legalbank).

37 Metin Günday, İdare Hukuku (10. Bası, İmaj 2011), 276; Kalabalık (n 1) 302.

38 Danıştay'a göre bu madde “ulusal mevzuatımızda kamulaştırmasız el atma kavramını tanımlayan ve bu durumda izlenecek usulü düzenleyen ilk yasal mevzuattır.” Danıştay 6 D, 2014/4122, 25.07.2014 (Legalbank).

39 Özel mülkiyete tabi taşınmazların kamu hizmetine tahsis edilmesi için öncelikle hukuka uygun olarak idarenin mülkiyetine geçmesi ve tahsis kararı alınması gerekmektedir. Bahtiyar Akyılmaz, Murat Sezginer ve Cemil Kaya, Türk İdare Hukuku (12. Bas1, Savaş 2020) 610 .

40 Yargitay HGK, 2005/352, 25.05.2005 (Legalbak).

41 Kamulaştırmasız el atmaya ilişkin olarak 221 sayılı Amme Hükmi Şahıslar veya Müesseseleri Tarafından Fiilen Amme Hizmetine Tahsis Edilmiş Gayrimenkuller Hakkındaki Kanunun 1. maddesiyle " 6830 sayılı İstimlâk Kanununun yürürlüğe girdiği tarihe kadar, kamulaştırma işlerine dayanmaksızın, kamulaştırma kanunlarının göz önünde tuttuğu maksatlara fiilen tahsis edilmiş olan gayrimenkuller ilgili âmme hükmi şahsı veya müessesi adına tahsis tarihinde kamulaştırılmış sayılır.". 
el koymayı "Usulü dairesince istimlak muamelesine tevessül etmeksizin Devlet ve diğer amme hükmi şahsiyeti tarafindan gayrimenkulü yola kalbedilen...." şeklinde tanımlarken usulüne uygun olarak kamulaştırma kararı alınmadan mülkiyet hakkının fiili durum sebebiyle hiçbir surette ihlal edilemeyeceğini belirtmektedir. ${ }^{42}$

Doktrinde ise kamulaştırma işlemi olmaksızın özel mülkiyette bulunan taşınmaza bir bedel ödemeden hukuka aykırı olarak idarece fiilen el konulması tanımlanmaktadır. ${ }^{43}$ Kamulaştırmasız el atma bir kanuna dayanmadığı ve buna istinaden idareye tanınan bir yetkinin olmaması, haliyle de tamamen usul dışı olduğundan "idarilik" vasfını taşımaması sebebiyle idari eylem olarak değil, haksız fiil olarak nitelendirilir. ${ }^{44}$

\section{Hukuki El Koyma}

Yargıtay 2010 yılında yeni bir içtihadıyla hukuki el koyma kavramını ortaya koymuştur. $\mathrm{Bu}$ kararında uzun yıllar programa alınmayan imar planının fiilen hayata geçirilmemesini, kamulaştırma ya da takas cihetine gidilmemesini, mülkiyet hakkının özüne dokunan ve onu ortadan kaldıran bir niteliğe sahip bulunması sebebiyle hukuki el atma olarak nitelendirerek, kamulaştırmasız el atma kapsamında değerlendirmiştir. ${ }^{45}$ Danıştay da bu yaklaşımı benimseyerek hukuki el atmayı benzer şekilde tanımlamaktadır. ${ }^{46}$ Kanun koyucu bu gelişmelere uzak kalmamış, 2016 yılında KK'na Ek1. maddeyi ekleyerek hukuki el atmayı kanun ile düzenlemiştir. Buna göre "Uygulama imar planlarında umumi hizmetlere ve resmî kurumlara ayrlmak suretiyle mülkiyet hakkının özüne dokunacak şekilde tasarrufu hukuken kısitlanan taşınmazlar hakkında, uygulama imar planlarının yürürlüğe girmesinden itibaren beş yıllık süre içerisinde imar programları veya imar uygulamaları yapılır ve bütçe imkânları dâhilinde bu taşınmazlar ilgili idarelerce kamulaştırılır veya her hâlde mülkiyet hakkını kullanmasına engel teşkil edecek kısıtlılığı kaldıracak şekilde imar planı değişikliği yapılır/yaptırılır". Görüldüğü üzere kanun koyucu hukuki el atmayı da kamulaştırmasız el atma olarak değerlendirerek KK' da düzenlemiştir. ${ }^{47}$ Dolayısıyla gerek fiili gerekse hukuki el atmanın bir üst kavram olarak kamulaştırmasız el atma olarak nitelendirilmesinde bir mahsur bulunmamaktadır.

42 Yargitay HGK, 1956/6, 16.05.1956 (Legalbank).

43 Aky1lmaz, Seziner ve Kaya (n 39) 652; Gözler, C.2 (n 29) 1014; Kalabalık (n 1) 303.

44 Günday (n 37) 277; Buna karşılık doktrinde kamulaştırmasız fiili el atmanın kamu hukuku alanında değerlendirilmesi gerektiği, idari eylem olduğu yönünde görüşler bulunmaktadır. İştar B. Tarhanlı, 'Uyuşmazlık Mahkemesi Kararları Işı̆̆ında Kamulaştırmasız El Atma' (1990) 11 (1-3) İHiD 41, 45.

45 Yargıtay HGK, 2010/651, 15.12.2010 (Legalbank); Kararın tahlili için bkz. Turan Yıldırım, 'İmar Planı Yoluyla Kamulaştırmasız El Atma' (2011) 7 (81-82) Bahçeşehir ÜHFKHHD 184, 194 ff.

46 Danıştay 6 D, 2014/4122, 25.07.2014 (Legalbank); Kamulaştııılması gereken yerin kamulaştırılmaması ve buna istinaden bedel ödenmemesi, taşınmazların mülkiyetinin davacıların üzerinde bırakılması nedeniyle, davacıların mülkiyet hakkının özüne dokunulduğu, taşınmazların süregelen şekilde kullanılamaması sonucunda demokratik toplum düzeninin gerekleriyle uyuşmayacak şekilde bu hakkın sınırlandırıldı̆̆ görülmektedir. Danıştay 6 D, 2014/1124, 18.02.2014 (Legalbank).

47 Benzer şekilde KK'nun kamulaştırmasız el atmayı düzenleyen G. 6. maddenin 10. fikrasının mülga 3. cümlesinde "Uygulama imar planlarında umumi hizmetlere ve resmî kurumlara ayrlmak suretiyle veya ilgili kanunların uygulamastyla tasarrufu kısıtlanan taşınmazlar..." hükmüne yer verilmişti. 
Doktrinde ise fili el atma ve hukuki el atma ayrımını reddedenler yanında kabul eden yaklaşımlar da bulunmaktadır. Ayrımı reddedenler hukuki el atmanın kamulaştırmasız el atma olarak nitelendirilemeyeceği, kamulaştırmasız el atma kavramının hukuka aykırı ve fiili el atma şeklinde gerçekleşebileceğini ifade etmektedir. ${ }^{48}$ Buna karşılık hukuki el atmanın da kamulaştırmasız el atma olduğu, idarenin kanunun verdiği yetkiye dayanarak tesis ettiği bir hukuki işleme (imar palanı) dayanarak, taşınmaz sahibinin mülkiyet hakkını kamulaştırma yapmaksızın uzun süre engellemesi veya kısıtlaması şeklinde gerçekleştiği ifade edilmektedir. ${ }^{49}$ Bunun yanında idarenin özel hukuk kişisinin taşınmazına fiili müdahalesi veya görev ve yetkisini aşarak imar mevzuatını mülkiyet hakkını ihlal eder şekilde uygulamasının fiili yol oluşturduğu, bununda haksız fiil niteliğinde olması nedeniyle her iki durumda da adli yargının görevli olacağı yolunda görüşler bulunmaktadır. ${ }^{50}$ Ancak fiili ve hukuki el atmanın ortak noktası taşınmaz sahibinin mülkiyet hakkının kısıtlanması ve her iki durumda da taşınmaz bedelinin ödenmemesidir. ${ }^{51}$ Dolayısıyla bir taşınmaza fiilen el atılarak mülkiyet hakkının kısıtlanması ile hukuken el atarak kısıtlanması arasında bir fark bulunmamaktadir. ${ }^{52}$

KK Ek1. maddesiyle imar planlarına dayanan kamulaştırmaların planın yürürlüğe girmesinden itibaren en geç beş yıl içinde kamulaştırılması zorunluluğu öngörülmüştür. Bütçe imkânlarını aştığı bu nedenle kamulaştırılamadığı takdirde, mülkiyet hakkındaki kısıtlamayı kaldıracak şekilde plan değişikliği yapılmalıdır. Madde Ek1'de dava açmadan önce uzlaşma yoluna gitme zorunluluğunu öngören hükmün Anayasa Mahkemesi tarafindan iptal edilmesiyle ${ }^{53}$, zorunlu idari başvurunun da bulunmaması sebebiyle, idare tarafından beş yıl içinde gerekli karar alınmadığı takdirde doğrudan dava yoluna gidilebilecektir. Maddeyle, kesin bir sürenin getirilmesi AHIM kararları ile de uyumu sağlamaktadır. AİHM, taşınmazın imar planında kamu hizmetine ayrılması ve buna istinaden idarenin herhangi bir süre sınırlaması olmaksızın, taşınmazı herhangi bir tarihte kamulaştırmaya yetkili olmasını, mülkiyet hakkının kullanımını belirsiz ve kullanılamaz hale getirdiğine ve adil dengenin sarsıldığına

48 Bazı eserlerde kamulaștırmasız el atma sadece fiili el atma kapsamında tanımlanmaktadır. Kaplan (n 34) 125, 127; Gözler C. 2 (n 29)1014 ff.; Hukuki el atmaya ilişkin görevli yargı merciinin idari yargı olması, çözüm usulleri ve sonuçlarının farklı olması sebebiyle kamulaştırmasız el atma olarak nitelenemeyeceği yaklaşımı konusunda bkz. Egemen Karaca, 'Kamulaştırmasız El Koymanın Unsurları ve Kamulaştırmasız El Koyamaya Karşı Yargısal Başvuru Yolları' 2018 (137) TBBD 273, 276-277.

49 Aky1lmaz, Sezginer ve Kaya (n 39) 652, 656.

s0 Kutlu Gürsel (n 12) 487.

51 Buna karşılık idare bir bedel ödemeden de taşınmazı hukuka uygun elde edebilir. İmar programına alınan taşınmaz üzerinde İmar Kanunu'nun 18. maddesi uygulanarak DOP alınırsa bu bedelsizdir. Bu madde kanunda belirtilen sebeplerle özel amaç için uygulandığından sınırlı bir uygulama alanı olmalıdır. Ayrıca mal sahibi söz konusu taşınmazı özgür iradesi ile rıza göstererek bedelsiz olarak da terk edebilir.

52 Yargıtay HGK, 2010/651, 15.12.2010 (Legalbank); Danıştay 6 D, 2013/2702, 14.04.2013 (Legalbank); Yıldırım, 'Kamulaştırmasız El Atma' (n 45) 184, 199.

53 Anayasa Mahkemesi, 2018/111, 20.12.2018. 
hükmetmektedir. ${ }^{54}$ AİHM, Sporrong ve Lönnroth/İsveç kararında mülkiyet hakkının barışçıl kullanımı bağlamında bu hakkın dokunulmazlığı; Mülkten mahrum bırakma, kamu yararı arasında adil denge; ve ayrıca kamu yararı amacıyla kanun taşınmaz kullanımını kontrol etmek olmak üzere üç temel unsuru olduğunu ifade etmektedir. AHIM, taşınmazların uzun süreli kamulaştırmasız hukuki el atma sebebiyle mülkiyet hakkının ihlal edildiği ve bu hakkın tanıdığı tüm imkânların kullanılması kısıtlanarak hakkın özüne dokunsa da, mülkiyet hakkının devam ettiğine, ancak kamu yararı ile mülkiyet hakk1 arasında adil dengenin bozulması sebebiyle tazmine karar vermektedir. Buna karşılık Ek1. maddesiyle hukuki el atma uygulama imar planları ile sınırlandığından, diğer alanlardaki sorunlara bir çözüm sunmamaktadır. Hukuki el atma uygulama imar planı dışında, başka bir düzenleyici ya da bireysel işlemle de olabilir. Örneğin Kültür ve Tabiat Varlıklarını Koruma Kültür Bölge Müdürlüğü’nün, belli bir yeri sit alanı ilan ederek tapuya şerh edilmesi sonrasında, bu alana ilişkin koruma imar planının ${ }^{55}$ uzun süre yapılmamasında da hukuki el atma mevcuttur. ${ }^{56}$

Yargıtay ve Danıştay hukuki el atmayı benzer tanımlasa da sorumluluğun kaynağını farklı değerlendirmektedir. Yargıtay'a göre imar planlarının zamanında uygulamaya geçirilmemesini, hareketsiz kalmasını idari eylem olarak nitelendirmektedir. ${ }^{57}$ Gerekçesinde idarenin görev ve yetki alanlarına giren konularda hukuka uygun olarak yaptığı fiiller ile bu görevleriyle ilgili hareketsiz kalmalarının idari eylem olduğunu, İmar Kanunu'nun ilgili maddeleri uyarınca tek yanlı idari işlemle düzenlenen imar planları ve bu planlara dayanılarak yapılan işlemlerin idari nitelik taşıdığı söz konusu imar planlarının zamanında uygulamaya geçirilmemesi durumunun da idari eylem niteliğinde olduğunu, buna karşıllk idarenin icra yetkisini hukuka aykırı olarak kullanması olarak nitelendirilebilecek fiili el atma durumu olmadığını belirtmektedir.

Danıştay ise imar planında kamu alanında kalan taşınmazın uzun süre kamulaştırılmaması sebebiyle uğranılan zararın idari eylemden kaynaklanmadığını, taşınmaza imar planında getirilen kısıtlamadan kaynaklandığını, diğer bir ifadeyle idari işleme dayandığını ifade etmektedir. ${ }^{58}$ Danıştay imar planını tamamlayan

54 Sporrong ve Lönnroth v Sweden App no 7151/75 (ECHR 23 September 1982); Hakan Arı v Turkey App no 13331/07, (ECHR 11 January 2011).

55 Kültür ve Tabiat Varlıklarını Koruma Kanunu m. 17/a uyarınca "Belediyeler, valilikler ve ilgili kurumlar söz konusu alanda üç yıl içinde koruma amaçlı imar planı hazırlatıp incelenmek ve sonuçlandırılmak üzere koruma bölge kuruluna vermek zorundadır. Üç yıllık süre içinde zorunlu nedenlerle plan yapılamadığı takdirde koruma bölge kurulunca gerekçeli olarak bu süre uzatılabilir".

56 Danıştay bu durumda kamulaştırılması zorunlu bir statüde bulunmadığı ve bu nedenle kamulaştırmasız el atma nedeniyle oluşan bir zarardan bahsedilemeyeceğine karar vermektedir. Danıştay 6 D, 2015/4418, 19.6.2015 (Legalbank); AİHM ise, taşınmazın tapu kaydına konulan şerhin mülkiyet hakkına etkisi olduğunu bunun mülkünün bir bölümüne tahdit getirdiğini, bu mahrumiyetin doğanın ve çevrenin korunması şeklindeki kamu yararına dayalı meşru bir amacının bulunduğunu, hukuka aykırı ve keyfî hiçbir işlem bulunmadığını belirtmiştir. Ancak AïHM, başvurucunun mülkiyet hakkından yararlanmasının engellendiği hâlde bir tazminat ödenmemiş olması nedeniyle kamu yararı ile başvurucunun mülkiyet hakkının korunmasının gereklilikleri arasındaki adil dengenin bozulduğu sonucuna varmıștır. Başvurucunun șahsi olarak olağan dıșı ve aşırı bir yüke katlanmış olduğu kanaatiyle başvurucunun mülkiyet hakkının ihlal edildiğine karar vermiştir. Köktepe v Turkey App no 35785/03, (ECHR 13 October 2009 (Legalbank).

57 Yargitay 18 HD, 2016/12989, 15.12.2016 (Legalbank).

58 Danıştay 6 D, 2014/213, 21.1.2014 (Legalbank). 
uygulama imar planı ve kamulaştırma gibi idari işlemleri yapmamadaki hareketsizlik üzerinde durmamıştır. Ancak bu hareketsizliği nitelendirmek gerekir.

İdari eylem hukuki durumlarda ya da dış dünyada hukuki sonuçları olan ve olumlu veya olumsuz hareket tarzıdır. ${ }^{59}$ İdari eylemler bir idari işlemin icrası şeklinde gerçekleşebileceği gibi, öncesinde bir idari işleme dayanmadan salt idari eylem olarak da gerçekleşebilir. ${ }^{60}$ Salt idari eylem dış dünyada bir değişiklik meydana getirme amaçlasa da, muhatabı açısından hukuki sonuç doğurabilmektedir. ${ }^{61}$ Ancak salt idari eylemi idari işlemden ayırt eden temel özellik, öncesinde hukuki sonuç doğurmaya yönelik bir irade beyanının olmamasıdır. ${ }^{62}$ İdari eylemler kanuna dayanır ve idari usuller izlenerek yapılması gerekmektedir. ${ }^{63}$ Buna rağmen özel hukuktaki haksız fiil ile idari eylemi ayırt etmek bazen zor olabilmektedir. Bu ayrım yapılırken idari eylemin hukuki sebebine ya da idari faaliyet ile arasında yer alan ilişkisine bakılmalıdır. İdare bir mevzuat hükmüne istinaden eylemde bulunuyorsa idari eylemin varlığı konusunda bir şüphe bulunmamaktadır. Bunun yanında idarenin eyleminin (tartışmasız bir şekilde) kamusal bir faaliyet ile doğrudan bir ilişkisi varsa veya kamusal bir konu ile sıkı ilişki içinde ise idari eylem olarak kabul edilir. ${ }^{64}$ Hukuki el atmada zarar, doğrudan idari işlemden değil, idarenin yükümlülüklerini yerine getirmede hareketsiz kalması sebebiyle mülkiyet hakkının belirsiz bir süre için kısıtlanmasından kaynaklanmaktadır. ${ }^{65} \mathrm{KK}$ Ek 1. maddenin yanında, İK'nun 10. maddesi uyarınca imar planının yürürlüğe girmesinden itibaren üç ay içinde beş yıllık imar programının hazırlanarak bu program süresinde kamulaştırmanın ya da diğer imar uygulamalarının yapılması zorunludur. ${ }^{66}$ Bu hüküm idareye takdir yetkisi tanımamakta, hukuki olarak el attığı taşınmazı bu süre içinde uygulamaya geçirmediği için hukuka aykırı davranmaktadır. ${ }^{67}$ İK. 10. maddeden farklı olarak KK Ek1. maddede taşınmaz üzerinde beş yıllık süre içinde imar uygulaması yapılmaması

59 Akyılmaz, Sezginer ve Kaya (n 39) 317; Markus Müller, Rechtsschutz gegen Verwaltungsrealakte, in: Pierre Tschannen (Hrsg.), Neue Bundesrechtspflege, Auswirkungen der Totalrevision auf den kantonalen und eidgenössischen Rechtsschutz (BTJP 2006) 320 .

$60 \quad$ Aky1lmaz, Sezginer ve Kaya (n 39) 317 ff.; Stefan Detterbeck, Allgemeines Verwaltungsrecht mit Verwaltungsprozessrecht (4. Bası, C.H. Beck 2006) 297; İdari eylemler farklı şekillerde tezahür etmekte ve belli başlıklar altında tasnif edilebilmektedir. İdari işlemin icrasına yönelik idari eylemler örneğin yıkım kararına istinaden yıkım yapılması; salt idari eylemler örneğin, belediyenin caddeleri temizlemesi, memurun dosya üzerinde çalışması, kamusal sağlık kuruluşlarında tıbbi müdahale, aşı yapılması, eğitimcinin sınıfta ders vermesi, gibi gerçek eylemde bulunma; bilgi ya da görüş verme şeklinde idari eylemler, kamu görevlisinin somut hukuki ve fiili konularda açıklama yapması, örneğin, bir yapının ya da değişikliğin ruhsata tabi olmaması yönünde yapılan açıklama; idarenin bilgi verici- açıklayıcı paylaşımı (willenserklaerung) şeklinde idari eylemler, zorlayıcı olmayan, idarenin toplumu uyarıcı ya da tavsiye edici eylemler. Örneğin, Tütün ürünlerinin zararına ilişkin kampanya, aşı olunması yönündeki tavsiyeleri gibi. Müller (n 59) 323 ff.; Maurer (n 8) 409.

61 Müller (n 59), 319-320.

62 Akyılmaz, Sezginer ve Kaya, (n 39) 319; Detterbeck (n 60) 297; Maurer (n 8) 408; Diğer farklılıklar için bkz. Talha Erdoğmuş, Salt İdari Eylem Karşısında İdarenin Sorumluluğu (1. Bası, XII Levha 2021) 15 ff.

63 Yargıtay İBK, 1959/15, 11.02.1959 (Legalbank); Erdoğmuş (n 62) 11.

${ }_{64}$ Detterbeck (n 60) 297.

65 Danıştay 6 D, 2015/4767, 30.06.2015 (Legalbank).

${ }_{66}$ Kalabalık (n 1) 267, 293; Akyılmaz, Sezginer ve Kaya, (n 39) 362; Danıştay 6D, 2013/7931, 04.12.2013 (Legalbank).

${ }_{67}$ Mülkiyet hakkına ilişkin konularda, idarenin beş yıl boyunca hareketsiz kalması, malikler lehine bazı haklar doğması bakımından yeterlidir. Danıştay IDDK, 2012/801, 24.05.2012 (Legalbank). 
veya kamulaştırılmaması durumunda, mülkiyet hakkındaki kısıtlılığın kaldırılması yönünde idarenin bir karar almasını emretmektedir. Bu bağlamda idarenin imar planlarını uygulamaya yönelik garanti edici idari işlemleri yapmamas1 ${ }^{68}$, hareketsiz kalması özel hukuk kapsamında değerlendirilemeyeceğinden idari eylem olarak nitelendirilebilir. ${ }^{69} \mathrm{Bu}$ durumda idari yargıdaki tam yarg1 davasının, IYUK'un 12. maddesine istinaden idari işleme dayanan bir dava mı? Yoksa IYYUK'un 13. maddesine göre salt idari eyleme dayanan bir dava olup olmadığının da tespiti gerekmektedir. IYYK'un 12. maddesine göre idari işleme dayanan tam yarg1 davasında 4 farklı alternatif söz konusudur. Doğrudan tam yargı davası, iptal ve tam yarı davasının birlikte, iptal davasının karara bağlanması üzerine tam yargı davası ve idari işlemin icrası nedeniyle tam yarg1 davası açılması mümkündür. ${ }^{70}$ Son alternatifte idari işlemin icrası kanaatimizce idarenin aktif davranışlarının (idari eylemle verdiği zararlar) yanında, olumsuz davranışları, diğer bir ifadeyle bir işleme (imar planına) istinaden yapmakla yükümlü olduğu garanti edici işlemleri yapmaması şeklindeki hareketsizliğini de kapsamaktadır. ${ }^{71}$

Anayasa Mahkemesi'nin bu konuda yaptığı değerlendirmede ise "davacının mülkü üzerinde tasarruf etme hakkının kısıtlanması, idarenin bir eyleminden değil, idari bir işlem niteliğinde olduğu tartışmasız olan imar planından kaynaklanmaktadır. Olayda, idarenin fiili el koyma niteliği taşıyan bir eylemi henüz bulunmamakta, aksine kanunen yapması gereken kamulaştırma işlemlerini yapmamak biçiminde tezahür eden bir eylemsizliği söz konusudur."72 Mahkeme kararında kısıtlamanın kaynağını bir taraftan idari işleme dayandırırken, diğer taraftan da aslında hareketsiz kaldığını belirterek idari eyleme dayandırmaktadır.

Uygulamada hukuki ve fiili el atmanın birlikte gerçekleştiği durumlar da söz konusu olabilmektedir. Örneğin uygulama imar planında yol olarak gösterilen özel mülkiyetteki bir taşınmaz hakkında, İK'nun 13/4. fikrası uyarınca beş yıllık imar programı süresi içinde herhangi bir kamulaştırma kararı almaksızın idarenin ${ }^{73}$, yol yaparak fiili olarak el atılmasında olduğu gibi. Bu durumda hukuki el atma için "yargı kararlarına göre” şartlar oluşmamışken, fiili el koymanın şartları oluşmuştur. Ya da

68 İmar planını uyulamaya yönelik imar programı yapma konusunda garanti edici bir işlemdir. Garanti edici işlem idarenin belli bir taahhüdünü içeren, idari makamın bir hizmeti yerine getirme yükümlülüğünü gösteren işlemlerdir. Bahtiyar Akyılmaz, İdari Usul İlkeleri Işı̆ğında İdari İşlemin Yapılış Usulü (1. Bası, Yetkin 2000, 56.

${ }^{69}$ Doktrinde idari eylem en geniş tanımıyla bir üst kavram olarak kullanılmaktadır. Buna göre idarenin idari işlem, idari sözleşme, plan, karar gibi klasik (hukuki) şekilde ortaya çıkan tasarrufları dışında kalan tasarrufları idari eylemdir. Müller (n 59) 317 ff.; İdarenin belli bir tasarrufta bulunması zorunlu iken, hareketsiz kalması idari eylem olmakla birlikte, doktrinde idarenin hareketsiz kalarak bir idari işlem tesis etmemesi durumunda, hareketsizliği hukuki duruma etki yapıp yapmadığına göre nitelendirmek gerekmektedir. Buna göre eğer idare olumlu ya da olumsuz bir cevap verseydi, idari işlem benzeri bir hukuki ilişki kurulacak idiyse idari işlem niteliğinde olduğu ifade edilmektedir. İbid 330.

70 Danıştay 6D, 2015/1893, 01.04.2015.

${ }^{71}$ Mülkiyet hakkı idarenin aktif bir tasarrufu ile ihlal edilebileceği gibi yapı ruhsatı talebine, idarenin bir karar almamasında olduğu gibi hareketsiz kalması durumunda da söz konusu olabilmektedir. Detterbeck (n 60) 396.

72 Anayasa Mahkemesi, 2013/101, 25.9.2013.

73 Danıştay IDDK, 2012/801, 24.5.2012 (Legalbank). 
taşınmaza beş yıllık süre geçtikten sonra fïlen el konulmasında hem hukuki hem fiili el atma şartları oluşmuştur. Hukuki el atmaya istinaden fiili el atma geçerli bir kamulaştırma ya da idarenin mülkiyetine geçmeyi sağlayan bir uygulama yapılmadığ sürece, doğrudan imar planına dayanılarak yapılması durumunda "idarilik" vasfı oluşmadığ 1 için idari eylem olarak da değerlendirilemez. Burada temel sorun aynı taşınmazdan kaynaklanan kamulaştırmasız el atmada farklı yargı kollarının görevli olması sebebiyle ortaya çıkabilecek farklı yargı kararlarının uygulanmasında da sorunun doğabilmesi ve hüküm uyuşmazlığı sebebiyle Uyuşmazlık Mahkemesine kadar gidebilecek ve adil yargılama hakkının ihlaline sebep olabilecek uzun bir yargılama süreci ortaya çıkabilecektir. Bu tür sorunları ortadan kaldırmak amacıyla en azında hukuki el atmaya dayanarak fiilen el atılan taşınmazlara ilişkin uyuşmazlıklar için aynı yargı kolunun görevli olması adil yargılama hakkına ve usul ekonomisi ilkesine hizmet edecektir.

Hukuki el atma konusunda uygulamada karşılaşılan sorunlardan bir diğeri de imar planlarında yol, park ve oyun parkı gibi kamu hizmetleri için ayrılan taşınmaz sahiplerinin idare tarafından terke zorlanabilmesidir. Taşınmaz sahibi yapı ruhsatı talebinde bulunduğunda imar planına göre ifraz isteyerek kamulaştırmasız hukuki el atılan yerlerin bedelsiz olarak terki talep edilebilmektedir. ${ }^{74}$ Taşınmaz sahibi bunu reddettiğinde imar planına aykırılık gerekçe gösterilerek ruhsat talebi reddedilebilmektedir. Bu sebeple uygulamada açılacak davaların uzun sürmesi, imar mevzuatında sıkça yapılan değişikliklerle otopark zorunluluğu, yapı alanı ve kat sınırlaması gibi yürürlüğe girecek değişikliklerden etkilenmemek için idarenin bu talebenin sıklıkla kabul edildiği görülmektedir. Dolayısıyla idareler hukuki el koyduğu taşınmazları terk yoluyla bedelsiz olarak elde edebilmektedir.

\section{Kamulaştırma Kanunu Uyarınca Malikin Taşınmazı Tekrar Elde Etme İmkânı}

KK, kamulaştırma usulünü ayrıntılı bir şekilde düzenlemektedir. Bu usulde mülkiyetin iktisabında KK'nun 8/1. fikrası uyarınca kamulaştırma kararına istinaden öncelikle satın alma usulü uygulanılarak taşınmaz sahibi ile uzlaşılmaya çalışılması gerekir. Uzlaşma sağlanırsa KK 8/5-6. fikralar uyarınca anlaşma tutanağının imzalanmasından sonra, idare adına tapuya tescil veya terkin ile mülkiyet el değiştirmektedir. Eğer taraflar uzlaşamaz ise idare KK 10/2. fikra uyarınca taşınmazın bulunduğu yer Asliye Hukuk Mahkemesinde bedel tespiti ve idare adına tescil davası açar. Taşınmaz sahibi mahkemece kendisine gönderilen meşruhatlı davetiyenin tebliğinden itibaren 30 içinde idari yargıda iptal davası açıp yürütmeyi durdurma kararı alırsa, Asliye Hukuk Mahkemesi KK 10/13. fikrası uyarınca bekletici mesele

\footnotetext{
Bedelsiz terk konusunda bkz. Ramazan, Yıldırım 'İdareye Taşınmaz Mal Kazandıran Bedelsiz Terk, Devir ve Temlikler' (2016) 11 (2) Karatay ÜHF 13 ff.
} 
yapmak zorundadır. Yürütmeyi durdurma kararı verilmezse yargılamaya devam olunur. Ancak bu da yeni uyuşmazlıklara neden olabilmektedir. Asliye Hukuk Mahkemesi idare adına tescil kararı verdikten sonra kamulaştırma kararı hukuka aykırı olması nedeniyle idari yarg1 yerince iptal edilirse iki farklı yargı kolu arasında hüküm uyuşmazlığg ortaya çıkacak ve yargılama süreci Uyuşmazlık Mahkemesine kadar uzayacak, adil yargılanma hakk1 ve usul ekonomisi ilkesine zarar verecektir. Ayrıca idari işlemin kamu düzenine ilişkin olması nedeniyle hukuka aykırı bir kamulaştırma kararına dayanan tescil kararı nedeniyle dolaylı olarak kamu düzeni de ihlal edilmiş olacaktır.

Kaldı ki yürütmeyi durdurma kararının verilmiş olması, esas bakımından işlemin iptal sonucunu da doğurmamaktadır. Yürütmeyi durdurma kararına rağmen idari yarg1 mercii davayı esastan reddedebilir. Dolayısıyla sadece yürütmeyi durdurma kararının verilmiş olmasına dayanan bekletici mesele yapma zorunluluğu, yargılama usulü bakımından da eşitsizliği beraberinde getirir. Bir taraftan yürütmeyi durdurma kararına rağmen esastan reddedilen dava, diğer taraftan yürütmeyi durdurma kararı olmadan esastan reddedilen ve hukuki sonuçları aynı olan bir dava bulunmaktadır. Birinde bekletici mesele yapma zorunluluğu olması diğerinde olmaması nedeniyle Asliye Hukuk Mahkemesinin yargılamaya devam ederek taban tabana zit kararlar çıkmasına neden olabilmektedir. İptal ihtimali olan bir kamulaştırma kararı nedeniyle dava yükü fazla olan hakime, yeni bir yük yüklememek gerekir. İdari yargıda açılan iptal davası kararının, adli yargı için bekletici mesele yapma zorunluluğunun getirilmesi konusunda kanun koyucunun bir düzenleme yapması elzemdir. Ancak, Asliye Hukuk Hakiminin idari yargıda açılmış olan kamulaştırma işleminin iptali davası varsa, bunu gerekçe yaparak HMK'nın 165. maddesi uyarınca bekletici mesele yapması önünde bir engel bulunmamaktadır. ${ }^{75}$ Doktrinde idari yargıdan bir karar çıkana kadar, Asliye Hukuk Mahkemelerinin en azından tescil kararı için idari yarg1 kararını beklemesi uygun olacağı yönünde görüşler bulunmaktadır. ${ }^{76}$

Nihayet Asliye Hukuk Mahkemesi bedel tespiti yaparak idare adına tescil kararı verir. Tescille birlikte taşınmaz mülkiyeti KK'nın 25. maddesi uyarınca idareye geçmiş olmaktadır. ${ }^{77}$ İdarenin mülkiyetine geçtikten sonra taşınmaza ihtiyacı kalmazsa, eski malike iade edebilir. Ayrıca Kanunda yer alan şartlar gerçekleşmişse eski malikin geri alma hakkı doğmaktadır.

KK'nun 21. maddesi idareye kamulaştırmadan tek taraflı vazgeçme yetkisi tanımaktadır. Buna göre idare kamulaştırmanın her safhasında tek taraflı olarak kısmen ya da tamamen vazgeçebilir. İdarenin kamulaştırma kararından vazgeçmesi,

75 HMK 165/1. fikraya göre; "Bir davada hüküm verilebilmesi, başka bir davaya, idari makamın tespitine yahut dava konusuyla ilgili bir hukuki ilişkinin mevcut olup olmadı̆̆ına kısmen veya tamamen bağll ise mahkemece o davanın sonuçlanmasına veya idari makamın kararına kadar yargllama bekletilebilir".

76 Kutlu Gürsel (n 12) 413.

77 İbid 546. 
kamulaştırma kararının geri alınması niteliğinde olduğundan bu yönde yeni bir idari işlemin tesis edilmesi gereklidir. ${ }^{78}$ Burada mülkiyet henüz idareye geçmediğinden, taşınmaz malikin mülkiyetinde kalmaya devam eder.

\section{A. Malikin Kamulaştırılan Taşınmazı Geri Alma Hakkı}

KK'nın 23. maddesinde yer alan şartlar gerçekleşmişse kamulaştırılan taşınmazın eski sahibinin geri alma hakkı doğmaktadır. Buna göre kamulaştırmayı yapan idare, kamulaştırma bedelinin kesinleşmesi tarihinden itibaren beş yıl içinde, kamulaştırma ve devir amacına uygun hiçbir işlem veya tesisat yapmaz veya kamu yararına yönelik bir ihtiyaca tahsis etmeyerek taşınmazı olduğu gibi bırakırsa, mal sahibi veya mirasçıları kamulaştırma bedelini aldıkları günden itibaren işleyecek kanuni faiziyle birlikte ödeyerek, taşınmazı geri alabilir. Eski malik geri alma hakkının doğmasından itibaren bir yıl içinde idareden taşınmazın kendine geri vermesini talep etmelidir. Eski mal sahibi süreci kendisi takip ederek şartların oluştuğunu tespit ederek resen başvurabilir. Ancak süreci takip etme gibi bir yükümlülüğü bulunmamaktadır. Buna karşılık idarenin, eski mal sahibinin geri alma hakkının oluştuğunu bildirmesi zorunludur. ${ }^{79}$ Aynı durum KK 22/4. fikra uyarınca taşınmaza ihtiyacı kalmayan idarenin, kamulaştırdığı taşınmazı kamu hizmeti amacıyla başka bir idareye devir veya tahsis etmemesi halinde de geçerlidir. Diğer bir ifadeyle devralan idare söz konusu taşınmazı süresi içinde kamu yararına yönelik bir hizmete tahsis etmezse eski mal sahibinin geri alma hakkı doğmaktadır. Bir yıllık süre hak düşürücü süre olduğundan, kaçırılması durumunda geri alma hakkı düşer. Bu süreler geçtikten sonra idareden herhangi bir hak, bedel ya da tazminat talebi bulunulamaz.

Kanunda geri alma hakkının istisnalarına yer verilmektedir. Buna göre KK ve özel kanunlarda bu maddenin uygulanmayacağına ilişkin hükümler bulunmaktadır. KK 3/2. fikra uyarınca Cumhurbaşkanınca kabul olunan, büyük enerji ve sulama projeleri ile iskân projelerinin gerçekleştirilmesi, yeni ormanların yetiştirilmesi, kıyıların korunması ve turizm amacıyla yapılacak kamulaştırmalarda, Arsa Üretimi ve Değerlendirilmesi Hakkında Kanununa göre yapılacak kamulaştırmalarda, Karayolları Genel Müdürlüğünün Hizmetleri Hakkında Kanun uyarınca görev alanına giren karayolunun yapımı, geliştirilmesi, çevresinin korunması ve düzenlenmesi ve/veya tesislerin yapımı için kamulaştırılan taşınmazlarda, Kanunun 22/3. fikrası uyarınca geri alma hakkı kullanılamaz.

\section{B. Kamulaştırılan Taşınmazın İdare Tarafından Malike İadesi}

Malike taşınmazını tekrar elde etme imkânı veren diğer bir durum ise idarenin ihtiyacı kalmayan taşınmazı iade etmesidir. KK'nın 22. maddesine göre

78 Akyılmaz, Sezginer ve Kaya (n 39), s. 645

79 Yargitay 18 HD, 2014/88, 13.01.2014 (Legalbank). 
kamulaştırmanın kesinleşmesinden sonra taşınmazın kamulaştırma amacına ya da kamu yararına yönelik bir ihtiyaca tahsisine gerek kalmamışsa, bu durum eski mal sahibine Tebligat Kanunu hükümlerine göre duyurularak, kendisinin ya da mirasçılarının kamulaştırma bedelini aldıkları günden itibaren işleyecek kanuni faizi ile birlikte üç ay içinde ödemek şartıyla taşınmazı geri alabilir. Eğer kamulaştırma ve bedelinin kesinleşmesinden sonra 1 yıl içinde iade gerçekleşirse faiz alınmaz. KK'nun 22. maddesi uyarınca taşınmazın iadesindeki amaç, kamulaştırılan malın idare tarafından kullanılmaması halinde, hem idarenin kamulaştırma bedeli oranında zarar etmesinin önüne geçmek, hem de taşınmazın hiçbir işe yaramadan atıl durumda kalmasına engel olmaktır. ${ }^{80}$

Taşınmazın iade edilebilmesi için kamulaştırma amacına ilişkin bir ihtiyacın kalmaması ya da kamulaştırmayı yapan idarenin başka bir hizmetine tahsis edilmemiş olması gerekmektedir. Ayrıca KK'nun 22/4. fikrası uyarınca başka bir idareye tahsis edilmiş ya da mülkiyet devredilmişse kamulaştırılan taşınmaz iade edilmez.

Taşınmazın iadesinde kamulaştırmanın kesinleşmesinden itibaren beş yıllık bir süre öngörülmüştür. Bu süre hak düşürücüdür. ${ }^{81}$

\section{Geri Alma ve Taşınmazın İadesinde Süre Sorunu}

Malikin taşınmazı geri alma ve idare tarafından iadesinde öngörülen sürelerin hak düşürücü süreler olduğunu yukarıda ifade etmiştik. Ancak burada süreler konusunda getirilen hükümlerin hangi tarihte yürürlüğe girdiğine bakarak ikili bir ayrıma gidilmesi gerekmektedir.

İş Kanunu İle Bazı Kanun ve Kanun Hükmünde Kararnamelerde Değişiklik Yapılması İle Bazı Alacakların Yeniden Yapılandırılmasına Dair Kanun'un ${ }^{82}$ 100. maddesi ile KK'nun 22. maddesine “Bu madde hükümleri, kamulaştırmanın kesinleşmesi tarihinden itibaren beş yıl geçmiş olması hâlinde uygulanmaz" ve "Bu madde hükümlerine göre taşınmaz malı geri almayı kabul etmeyen mal sahibi veya mirasçılarının 23 üncü maddeye göre geri alma hakları da düşer" fikraları eklenmiştir. KK'nun 23. maddesine eklenen "birinci ve ikinci fikrada belirtilen süreler geçtikten sonra kamulaştırılan taşınmaz malda hakları bulunduğu iddiasıyla eski malikleri veya mirasçllar tarafindan idareden herhangi bir sebeple hak, bedel veya tazminat talebinde bulunulamaz ve dava açılamaz" fikrası, bu hükümlerin yürürlüğe girdiği tarihten sonraki uyuşmazlıklarda uygulanabilir. Madde hükümleri 11 Eylül 2014 tarihinde yürürlüğe girdiğinden bu tarihten sonra uygulanacaktır. Anayasa Mahkemesine göre maddenin yürürlüğe girmesinden önce kesinleşmiş

\footnotetext{
80 Yargitay HGK, 2007/849, 14.11.2007 (Legalbank).

${ }^{81}$ Yargitay 5 HD, 2014/25072, 05.11.2014 (Legalbank),

82 Kanun Tarihi: 10.09.2014, Kabul numarası: 6552, RG 11.09.2014/29116.
} 
mahkeme kararlarında bu süre geçerli değildir. Anayasa Mahkemesi; “...ihlal iddiasına konu taşınmaza iliş̧kin olarak tazminat istemiyle açılan davada verilen karar Yargitay Dairesince karar düzeltme isteminin reddedildiği 30/5/2013 tarihinde kesinleşmiş olup geri alma hükümlerine dayalı dava açma sürelerini sınılayan ve 2942 sayll Kanun'a 10/9/2014 tarihli ve 6552 sayll Kanun'un 100. maddesiyle eklenen 22. maddesinin ikinci ve ü̧̈üncü fikraları, 23. maddesinin ü̧̈üncü fikrası ile geçici 9. madde hükümlerinin somut olayda uygulanma olanağının bulunmadığ anlaşılmaktadır." 83 şeklinde karar vermektedir. Mahkeme bu hükmüyle söz konusu sürelerin maddenin yürürlük tarihi olan 11.09.2014 sonrası kesinleşen mahkeme kararlarında uygulanacağını açıkça ifade etmektedir. Yargıtay'ın Kanunda değişiklik yapılmadan önceki kararlarına bakıldığında 22. madde bağlamında iadede süre sınırı olmadığı yönünde istikrar kazanmış kararları bulunmaktadır ${ }^{84}$ Yine Yargıtay'a göre; 22. madde uyarınca taşınmazın iadesindeki amaç, kamulaştırılan malın idare tarafından kullanılmaması halinde, hem idarenin kamulaştırma bedeli oranında zarar etmesinin önüne geçmek, hem de taşınmazın hiçbir işe yaramadan atıl durumda kalmasina engel olmaktır. ${ }^{85}$

Yukarıdaki açıklamalar 1şığında 22. maddede öngörülen sürelerin Kanunun yürürlüğe girmesinden önce uygulanmayacağını, aynı şeklide 23. madde uyarınca da geri alma hakkına ilişkin beş ve bir yıllık süreler geçtikten sonra da eski mal sahibi ve mirasçıların idareden hak, bedel ve tazminat talepleri ile dava haklarını kaldıran fikranın yürürlüğe girmesinden önce uygulanamayacağı sonucuna varabiliriz.

\section{Kamulaştırmasız EI Koyma Nedeniyle Malikin Taşınmazı Tekrar Elde Etmesi}

Kamulaştırmasız el konulan taşınmazlarda mülkiyet idareye geçmediğinden idare tarafından iade ya da malikin geri alma hakkı gibi bir durum söz konusu değildir. Buna karşılık kamulaştırmasız fiili ya da hukuki el atılan taşınmazın idarenin mülkiyetine geçmesinden sonra malike iadesi ya da malikin geri alma hakkı konusunda bir hüküm bulunmamaktadır. İdarelerin kamulaştırmasız el attığı taşınmazlara ihtiyacı kalmaması ya da kamu hizmetine yönelik herhangi bir faaliyette bulunmaması (tahsis etmemesi) durumunda KK hükümlerinin uygulanıp uygulanmayacağı hususunda belirsizlik bulunmaktadir.

$\mathrm{Bu}$ konuya geçmeden önce kamulaştırmasız el koyma durumunda mülkiyetin idareye geçme hallerine yer vermek uygun olacaktır.

\footnotetext{
Anayasa Mahkemesi ikinci bölüm, B. No: 2013/6151, 21.04.2016.

${ }^{84}$ Yargitay 18 HD, 2014/88, 13.01.2014 (Legalbank); Yargitay 18 HD, 2011/8016, 30.06.2011 (Legalbank).

85 Yargitay HGK, 2007/849, 14.11.2007 (Legalbank).
} 


\section{A. Kamulaştırmasız Fiili El Koymada Mülkiyetin İdareye Geçmesini Sağlayan Durumlar}

Kamulaştırmasız el koymada taşınmaz sahibinin başvuracağı hukuki yollar bulunmaktadır. Ancak KK Geçici 6. maddesiyle özel hüküm getirerek 09.10.1956 04.11.1983 tarihleri arasındaki kamulaştırmasız el atmada bu özel usulün uygulanmas1 öngörülmektedir.

\section{Kamulaştırmasız EI Atmada Genel Usul}

Kamulaştırmasız el atma nedeniyle idarenin müdahalesine son vermek amaciyla müdahalenin meni, el konulan taşınmazın bedelini talep ederek mülkiyetin idareye geçmesi için bedel davası, uğramış olduğu zararların giderilmesi için tazminat ve haksız işgal sebebiyle ecrimisil davası açılabilir. ${ }^{86} \mathrm{Bu}$ davaların bir kısmı birlikte açılabileceği gibi ayrı ayrı da açılabilir.

Müdahalenin meni davasında idarenin taşınmazı tahliye etmesine karar verilebilir. $\mathrm{Bu}$ takdirde mülkiyet taşınmaz sahibinde kalır. Taşınmaz sahibi buna istinaden idarenin hukuka aykırı olarak mülkiyet hakkına müdahalesinden kaynaklanan zararların giderilmesi amacıyla tazminat davası ve taşınmazın haksız işgali sebebiyle ecrimisil davası açabilir.

Bedel davası açarsa malik mülkiyetin idareye geçmesine rıza göstermekte ve taşınmazın idare adına tescilini isteyebilmektedir.

\section{Kamulaştırmasız El Atmada Özel Usul}

KK Geçici 6/1. maddesine göre malikin rızası olmadan taşınmaza fiili olarak el konulması sebebiyle, mülkiyet hakkından doğan taleplerde, bedel talep edilmesi hâlinde bedel tespiti ve diğer işlemlerde, öncelikle uzlaşma usulünün uygulanması dava şartıdır. Taşınmaz sahibinin önce idareye başvurması zorunludur. Bir sonuç çıkmaz ise dava yoluna başvurabilecektir. Bu usul süreci sonunda taşınmaz idarenin mülkiyetine geçmektedir. Bu özel usul yukarıda belirtilen tarihler arasında fiili el konulan taşınmazın mülkiyetinin idareye geçmesini öngörmektedir. Taşınmaz sahibinin mülkiyetin el değiştirmesi konusunda bir hakkı olmasa da bedele ilişkin haklara sahiptir.

\section{a. İdare İle Uzlaşma}

KK Geçici 6. maddesine göre idarenin daveti ya da malikin başvurusu üzerine uzlaşma görüşmeleri başlamakta, talep sahibinin uzlaşma görüş̧melerine davet edilmesinden itibaren 6 ay içinde sonuçlandırılması gerekmektedir. Uzlaşma 
görüşmelerinde mülkiyet hakkından doğan talepler ve bu bağlamda uzlaşılan hakkın türü ve varsa bedel üzerinden bir sözleşme akdedilir. Eğer taşınmazın mülkiyetinin idareye devri ve karşılığında bedelini ${ }^{87}$ ödeme konusunda anlaşılmışsa uzlaşma konusu taşınmaz resen tapuya tescil ve terkin edilmektedir. Buna istinaden taşınmazın mülkiyeti idareye geçer.

\section{b. Yargısal Başvurular}

KK Geçici 6/6. fikrası uyarınca uzlaşma görüşmeleri sonuçsuz kalırsa uzlaşmazlık tutanağı düzenlenir. Tutanağın düzenlenmesinden itibaren taşınmaz sahibi malik ya da idare bedel tespiti davası açabilir. Bu takdirde mahkeme bedel tespiti yaparak taşınmazın idare adına tesciline veya terkinine hükmeder. Tescile veya terkine ilişkin hüküm kesin olup tarafların hükmedilen bedele ilişkin kanun yolu hakkı saklıdır. Bu hükme istinaden taşınmaz sahibi ancak bedele ilişkin dava açabilir.

\section{B. Kamulaştırmasız Hukuki El Atmada Mülkiyetin İdareye Geçmesini Sağlayan Durumlar}

KK Ek 1. madde uygulama imar planlarının yürürlüğe girmesinden itibaren beş yıllık süre içerisinde imar programları veya imar uygulamaları yapılarak ve bütçe imkânları dâhilinde bu taşınmazlar ilgili idarelerce kamulaștırılacağı düzenlendiğinden, öngörülen sürede bu kararlar alınmazsa, mülkiyet hakkını kullanmasına engel teşkil edecek kısıtlılığı kaldıracak şekilde imar planı değişikliği yapılacağını belirtmektedir. $\mathrm{Bu}$ hükümle getirilen asıl yenilik ise taşınmaz hakkında beş yıl içerisinde idarenin mülkiyetine geçirilecek karar alınmazsa, kısıtllılı̆g kaldıracak şekilde plan değişikliği yapılması, aksi takdirde malike iade edilmesi gerekmektedir. Danıştay’a göre de Ek1. maddeyle "en geç beş yıllık süre içerisinde bütçe imkanları dahilinde ilgili idarelerce kamulaştırılması veya taşınmazların mevcut imar planı bulunup bulunmadı̆̆ veya imar planı yapılabilecek yerlerden olup olmadiğı durumuna göre imar planı/imar uygulaması/toplulaşma yapılmak/yaptırılmak suretiyle başka yerden mümkün ise müstakil, değilse hisseli parsel verilmesi veyahut taşınmazların tahliye edilerek kullanıma imkan verecek biçimde malikine iade edilmesi amaçlanmıştır" ${ }^{88}$

Kanun hükmü her ne kadar mülkiyet hakkının özüne dokunacak şekilde tasarrufu hukuken kısıtlanan taşınmazları bu kapsama alsa da ${ }^{89}$ yukarıda ifade edildiği üzere imar planlarının yapılmasıyla birlikte süresi içinde gerekli kararlar alınmadığı,

87 KK Geçici 6/3. fikraya göre uzlaşma; idareye ait taşınmazın trampası, idareye ait taşınmaz üzerinde sınırlı ayni hak tanınması veya imar mevzuatı çerçevesinde başka bir yerde imar hakkı kullandırılması suretiyle veya bunların mümkün olmaması hâlinde nakdi bedel üzerinden yapılabilir.

88 Danıştay 6 D, 2016/4782, 20.09.2016 (Legalbank); Danıştay 6 D, 2015/6995, 20.09.2016 (Legalbank).

89 Doktrinde mülkiyet hakkının özüne dokur şekilde kısıtlanması durumunda madde kapsamına girdiği, hakkın özüne dokunmayan kısıtlamalarda ise idari yargıda mülkiyetin bedele çevrilmesi için dava açılacağı yönünde görüşler bulunmaktadır. Yalçınduran (n 5) 491, 507 ff. 
kamulaştırma yapılmadığı ve bazı haklar kullanılamadığından, kamulaştırmasız hukuki el atma nedeniyle AHİM, Danıştay ve Yargıtay ve kararlarında da belirtildiği üzere mülkiyet hakkının özüne dokunur şekilde kısıtlanmaktadır. Dolayısıyla bu hüküm imar planının uygulama kapsamına giren tüm taşınmazlar için uygulanabilir niteliktedir. Buna göre taşınmazlar kamulaştırma yoluyla idarenin mülkiyetine geçebilmektedir. Kamulaştırma ya da diğer uygulamalarla beş yıllık süre zarfında taşınmazlar idarenin mülkiyetine geçirilmezse, hükmün emredici olması nedeniyle kısıtlılığ 1 kaldıracak şekilde imar planı yapılması zorunludur. Aksi durumda mülkiyet taşınmaz sahibinde kalmaya devam etmekte ve hukuki el atma gerçekleşmektedir. Beş yıllık sürenin maddenin yürürlüğe girdiği tarihten sonra başlayacağını düzenleyen KK Geçici 11. maddenin Anayasa Mahkemesi tarafından iptal edilmesiyle ${ }^{90}$ birlikte, Ek1. maddenin yürürlüğe girmesinden önceki imar planlarında süre planın yürürlüğe girdiği tarihten başlayacaktır. Beş yıllık süre geçmesine rağmen idare kısıtlılığı kaldırmaz ve malike taşınmazı iade etmezse yapılacak idari başvuru ile iptal davası açılıp, bununla birlikte uğranılan zararlarda istenebilecektir.

Kamulaştırmasız hukuki el atılan taşınmazların mülkiyeti taşınmaz sahibinde kalmakla birlikte mülkiyet hakkının kısıtlanması sebebiyle uğradığı zararları tam yarg1 davasıyla idareden isteyebilmektedir. İdare bu süreçte kamulaştırma ya da DOP yoluyla mülkiyeti kazanabilir. Kamulaştırdıktan sonra da şartlar oluşursa eski malik iade veya geri alma hakkını kullanabilir. İdari yargıda açılacak iptal davasıyla Danıştay içtihatlarına göre idare kamulaştırmaya zorlanamayacağından bu usulde mülkiyetin idareye geçmesi zor görünmektedir.

KK Ek 1/ 2. fikrası ile Asliye Hukuk Mahkemesinde kamulaştırmasız el atmaya uygulanan usule benzer bir usul idari yargı için de öngörülmüştü. Buna göre "birinci fikra uyarınca dava açılması hâlinde taşınmazın ya da üzerinde tesis edilen irtifak hakkının dava tarihindeki değeri, mahkemece; bu Kanunun 15 inci maddesine göre bilirkişi incelemesi yapılarak, taşınmazın hukuken tasarrufunun kısıtlandiğı veya fiilen el konulduğu tarihteki nitelikleri esas alınmak suretiyle tespit edilir ve taşınmazın veya hakkın idare adına tesciline veya terkinine hükmedilir". İdari yargının idare adına tescil kararı verememesinden, taşınmaz bedelini ödeyen idarenin aynı yarg1 kararıyla mülkiyeti kazanamamasından kaynaklanan sorunların giderilmesi amacıyla ${ }^{91}$ getirilen bu fikra başka sorunlara neden olmuştur. Özellikle taşınmazın veya hakkın idare adına tescil veya terkinine de karar vereceği hükmü idari yargı mercilerince IYUK 2. madde uyarınca iptal kararı ve tam yarg1 davas1 (tazminata hükmetme) dışında idare adına tescil veya terkin kararı veremeyecekleri, bunun adli yargının görevine girdiği bahsiyle uygulama alanı bulamamıştır. İdari yargı mercileri “...hükmedilen kamulaştırma bedelinin söz konusu taşınmazın davacı

90 Anayasa Mahkemesi, 2018/34, 28.3.2018.

91 Emrah, Kulaklı, ‘'̇ari Yargının Görevli Olduğu Kamulaştırmasız El Atma Davalarında Taşınmazın Tescili Sorunu' (2015) 2 (1) İstanbul Medipol ÜHFD 185, 192-193. 
tarafindan her türlü kisitlamadan ari olarak davalı idare lehine ferağ vermesi koşuluyla ödenmesine" hüküm tesis etmeye devam etmiştir. ${ }^{92}$ Dolayısıyla taşınmaz sahiplerinin kendi rızaları ile tapuda ferağ vermesi, vermezlerse idarenin ayrıca adli yargıda tapu iptali ve tescil davası açması gerekmekteydi. ${ }^{93}$ Anayasa Mahkemesinin KK Ek 1/2. fikrayı iptal etmesiyle birlikte bu duruma son verilerek ${ }^{94}$, idari yargida önceki usule tekrar dönülmüştür. Dolayısıyla beş yıllık imar programı içinde kamulaştırılmayan yerler için taşınmaz sahipleri idareye başvurarak, kamulaştırmasını isteme ve uğranılan zararların giderilmesini isteyebilecektir. Zımni ya da açık ret üzerine idari yargıda işlemin iptali ile birlikte uğranılan zararların giderilmesi için tam yargı davası açabileceklerdir. Her ne kadar Danıştay, idari yargının idareleri kamulaştırmaya zorlayıcı kararlar vermesinin mümkün olmadığını belirtse de ${ }^{95}$, yargı kamulaştırma kararı vermemekte, idari başvuruya ilişkin idarenin ret kararının diğer iptal davalarında olduğu gibi iptali istenmektedir. İdarenin yükümlülüğünde bulunan bir kamulaştırmayı yapmaması sebebiyle iptal edilmesi durumunda, IYYUK'un 28. maddesi uyarınca tersine bir işlemle kamulaştırma kararını idare alacaktır. ${ }^{96}$

KK Ek 1. maddede beş yıllık süre içerisinde kamulaştırma, diğer uygulama ya da kısıtllı̆ğın sona erdirilmesini öngörmesi sebebiyle, bu süreyi aşması durumunda şartları oluşacak hukuki el atmaya istinaden idari yargı organlarının idarenin kamulaştırmaya zorlanamayacağına karar vermesinden ötürü mülkiyetin idareye geçmesi zor görünmektedir. Buna rağmen el atma devam ederse idari başvuru yaparak iptal davasıyla birlikte ya da doğrudan tam yargı davasıyla taşınmazın bedele çevrilmesinin istenmesi önünde bir engel bulunmamaktadır. Bu yönde bir karar çıkarsa taşınmaz sahibi tapuda idare adına ferağ vererek, ya da idare adli yargıda tapu iptalini ve tescilini isteyecektir. Taşınmazın mülkiyeti bu şekilde iktisap edilecektir.

KK Ek 1/2. fikranın yürürlükte olduğu dönemde idarenin mülkiyetine geçen taşınmazların eski sahibinin taşınmazına kavuşmasını sağlayan hükümlerin kıyasen uygulanabilirliği konusunda fiili el atmadaki gibi belirsizlik bulunmaktadır.

\section{Kamulaştırma Kanununun Kıyasen Uygulanması Sorunu}

KK'nun, kamulaştırmasız el atma sonrasında idarenin mülkiyetine geçen taşınmazlara da uygulanacağı hususunda bir hüküm bulunmamaktadır. Buna karşılık, kamulaştırmasız el koymalarda bedele ilişkin hükümlerde olduğu gibi birçok konuda Kanunun kıyasen uygulanacağı hüküm altına alınmaktadır. Burada açıklanması gereken sorun, kanunda açık bir hüküm olmasa da, kamulaştırmasız el koyma

92 İstanbul 9 İdare Mahkemesi, 2015/443, 10.03.2015; İstanbul 1 İdare Mahkemesi, 2014/2390, 26.12.2014. Nakleden İbid 193.

93 İbid 193.

94 Anayasa Mahkemesi, 2018/111, 20.12.2018.

95 Danıştay 6 D, 2009/5534, 13.5.2009 (Legalbak); Danıştay 6 D, 5794, 10.12.2002 (Legalbank).

96 Kalabalık (n 1) 299 ff. 
sonrasında yukarıda belirttiğimiz usuller izlenerek idarenin mülkiyetine geçmiş olan taşınmazın, idare tarafından eski malike iadesi ve malikin geri alma hakkının bulunup bulunmadığıdır. Diğer bir ifadeyle, malike iade ve malikin geri alma haklarına ilişkin KK'da yer alan hükümler, kamulaştırmasız el konulan taşınmazın idarenin mülkiyetine geçmesinden sonra kıyas yoluyla uygulanabilir mi?

\section{A. Kiyas Kavramı}

Kıyas, kanunda belli bir olay için konulmuş olan bir hükmün, kanunla düzenlenmemiş benzer bir olaya uygulanmasıdır. ${ }^{97}$ Tanımdan da anlaşılacağı üzere kıyas yoluyla akıl yürütebilmek için sözkonusu olaya uygulanabilecek bir pozitif düzenlemenin olmaması, bir boşluk olması gerekir. Bu açıdan olaya ilişkin mevcut bir hükmün yorumlanmasından farklılık arz eder. Kanun metnine bağlı kalmak kaydıyla lafzı anlamının ötesinde kelimelerin çok geniş yorumlanması dahi, doğru yanlış olması bir tarafa, kanunla bağlantıyı koparmaz. ${ }^{8}$ Dolayısıyla yorum kanunu uygulamakta kullanılan bir yöntem, kıyas ise mevcut bir hükmün genişletilerek benzer bir olaya uygulanmasıyla kanun boşluğunu dolduran, bir nevi o konuya ilişkin kural koyma anlamına gelmektedir.

Kıyas yoluna başvurulabilmesi için kıyaslanan konuda kanunda hüküm olması, bu hükmün istisnai olmaması, kıyaslanan olaya ilişkin bir hükmün olmaması ve kıyas konusu olayın kıyaslanan olay ile sebep ve amaç bakımından aynı niteliğe haiz olması gerekmektedir. ${ }^{99} \mathrm{Bu}$ şartlarla birlikte kanun hükmüyle düzenlenen sonucun da mevzubahis olaya uygulanabilir olması gerekmektedir. ${ }^{100}$ Kanun koyucu kıyas 1 açıkça düzenleyerek izin verebileceği gibi, yasaklayabilir de. Bunun yanında kıyas konusunda herhangi bir hükme yer vermeyebilir. ${ }^{101} \mathrm{Bu}$ durumda kiyas yapılıp yapılmayacağını hukukun alanına ve temel ilkelere göre tespit etmek gerekmektedir. Kanunda kıyasa ilişkin hüküm bulunmayan hallerde, kıyasa cevaz veren hukuk dallarında kıyas yoluna gidilebilecektir. ${ }^{102}$

Kanunda, kıyasen uygulama konusunda açık bir hüküm varsa kanun boşluğundan bahsedilemez. Danıştay bu durumda kıyasın mevcut olmadığını, kanunlar arası bir atfın yapıldığını, bunun da doğrudan kanuni bir düzenleme olduğunu belirtmektedir. ${ }^{103}$

\footnotetext{
7 Adnan Güriz, Hukuk Başlangıcı (19. Bası, Siyasal 2019) 101; Necip Bilge, Hukuk Başlangıcı (22. Bası, Turhan 2007) 204; Kemal Gözler, Hukukun Genel Teorisine Giriş, Hukuk Normlarının Geçerliliği Ve Yorumu Sorunu (1 Bası, US-A 1998) 173;, Gökhan Antalya, Hukuk Teorisi ve Hukuk Metodolojisi, C.1 (1. Bası, Seçkin 2019) 525; Kıyasın hukukta faydalı olup olmadığı, etkili bir akıl yürütme yöntemi olup olmadığı hususunda tartışmalar için bkz. Aslan Topakkaya, Hukuk Hermeneutiği, Hukukta Anlama ve Yorumlama Sanatı, (1 Bası, Adalet 2019) 41, 51 ff.

98 Gözler, Hukukun Genel Teorisine Giriş (n 97) 183.

99 Kemal Gözler, Hukuka Giriş (16. Bası, Ekin 2019) 368.

100 Thorsten Ingo Schmidt, 'Die Analogie im Verwaltungsrecht' (2006) 97 (2) VerwArch 139, 146.

101 Gözler Hukukun Genel Teorisine Giriş (n 97) 175.

102 Bilge (n 97) 204.

103 Danıştay 1 D, 2020/293, 3.3.2020 (Lexpera).
} 
Kanun koyucu daha çok ilgili kanunlarda tekrar yapmaktan kaçınmak amaciyla bu yönde hükümler tesis etmektedir. Bunlar ilgili kanunda yer alan hükümlerin uygulanması ya da başka bir kanun hükmünün uygulanması şeklinde karşımıza çıkabilmektedir. Kıyas daha çok gerçek kanun boşluğunda, yani herhangi bir hükmün bulunmaması durumunda bu boşluğun doldurulması için yapılmaktadır. ${ }^{104}$

Özel hukukta kıyas yasağı öngörülmediğinden, kıyasa genel olarak cevaz verilmektedir. ${ }^{105} \mathrm{MK}$ 1/2. fikrasına göre; "Kanunda uygulanabilir bir hüküm yoksa, hâkim, örf ve âdet hukukuna göre, bu da yoksa kendisi kanun koyucu olsaydı nasıl bir kural koyacak idiyse ona göre karar verir.”. Bu hüküm özellikle kanunda mevcut olan boşlukların doldurulmasında hakime kendi hukuk kuralını yaratabilmesi yanında kıyas yoluyla da hukuk kuralı yaratmasına izin vermektedir. ${ }^{106}$ Bunun yanından özel hukuk ilişkilerini düzenleyen birçok kanun başka hükümlere atıfta bulunarak kıyas yoluyla uygulamayı düzenlemektedir. Örneğin BK'nın 246. maddesine göre taşınır satışına ilişkin kurallar kıyas yoluyla taşınmaz satışına da uygulanır.

Kamu Hukuku'nda kıyas yasağı ve kıyas serbestisi uzun süredir tartışılan ve farklı görüşlerin ortaya çıktığı bir konudur. Bu görüşler Kamu Hukuku’nun dalları olan Anayasa, Ceza, Vergi ve İdare Hukuku'nun özelliğine göre değişmektedir. Doktrinde Kamu Hukuku alanında hukuk güvenliği bakımından kesin kıyas yasağını savunan görüşler ağırlıklı olarak kanunilik ilkesine dayanmaktadır. ${ }^{107}$ Buna karşın istisnai hükümler dışında bazı hallerde kıyasın varlığını kabul eden görüşler bulunmaktadır. ${ }^{108}$

Kamu Hukuku'nda kıyas serbestisi ya da yasağı konusunda kişi aleyhine yükümlendirici nitelikte kıyas ve lehine hak doğurucu kıyas olmak üzere ikiye ayrılarak incelenmesi gerekir. Bu açıdan bakıldığında her iki durumda da kıyas serbestisini savunan görüşler bulunmaktadır. ${ }^{109}$ Ağırlıklı görüş kişi aleyhine yükümlendirici kıyasın yasak olduğu, kişi lehine hak yaratıcı durumlarda ise kıyas serbestisinin bulunduğu yönündedir. ${ }^{110}$ Kamu hukukunda geniş kapsamlı kıyas, kanunla öngörülen idari faaliyetin öngörülebilirliğini olumsuz yönde etkileyerek hukuki güvenliği zedeleyebileceğinden kıyasın şartlarını aşacak şekilde yapılmaması gerekir. ${ }^{111}$

\footnotetext{
04 Çiğdem Kırca, 'Örtülü (Gizli Boşluk Ve bu Boşluğun Doldurulması Yöntemi Olarak Amaca Uygun Sınırlama (Teleologische Reduktion)'(2001) 50 (1) AÜHFD 91, 97.

105 Ingo Schmidt (n 100) 139, 162.

106 Antalya (n 97) 525.

107 Şaban Kayıhan, Hukukun Temel Kavramları (7. Bası, Seçkin 2017) 245.

108 Kemal Gözler, Kamu Hukukçuları Platformu, Anayasa Hukukunda Yorum ve Norm Somutlaşması, Tebliğler (TBB 2012) 61, 65, 71; Failin lehine olan kurallar kanunilik ilkesine aykırılık taşımamakta, kıyasa yasağı failin lehine uygulamalara engel olmamaktadır. İçel Kayıhan ve Süheyl Donay, Karşılaştırmalı ve Uygulamalı Ceza Hukuku, Genel Kısım 1 (1. Bası, Beta 2005) 88.

109 Michael Sachs, $\$ 44 V w V f G$, in: Stelkens/Bonk/Sachs (Hrsg.), VwVfG Kommentar (6. Bas1, C.H. Beck 2001) Rn. 53.

110 Christoph Gusy, 'Richterrecht und Grundgesetz' (1992) 45 (11) DÖV 461, 464.

111 Guy Beaucamp, 'Zum Analogieverbot im öffentlichen Recht'(2009) 134 (1) AöR 83, 99.
} 
İdare Hukuku'nda, kesin kıyas yasağı bulunmamakla birlikte özel hukukta olduğu gibi bir kıyas serbestisi bulunmamaktadır. ${ }^{112}$ Kanun koyucu, kanunda bazı maddelere atıfta bulunarak kıyasen uygulanacağını hüküm altına almasında kanun boşluğu olmadığından doğrudan uygulanır. İdare hukuku mevzuatı kanunlara açıkça atıf yaparak diğer kanun veya madde hükümlerinin kıyas yoluyla uygulanacağını açıkça hüküm altına almaktadır. ${ }^{113}$ Danıştay, hukuk boşluğunun ortaya çıktığı durumlarda MK'nın 1/2. fikrası uyarınca, bu boşluğun idari yarg1 organlarınca doldurulması gerektiğine karar vermektedir. ${ }^{114}$ Hukuk boşluğunu doldururken de kıyas yoluyla akı1 yürütebilmektedir.

İdare Hukuku'nda kıyasın uygulanabilirliği konusunda, hak yaratıcı durumlarda ve yükümlülük getiren durumlarda kıyas arasında ayrım yapılarak konunun incelenmesi gerekir. Yükümlendirici işlemler kişilerin hukuk güvenliğini zedeleyebildiğinden kıyas yasağının kabulü gerekir. Özellikle suç ve cezalara ilişkin hükümler, yaptırım içeren hükümlerde kıyas yapılamaz. ${ }^{115}$ Buna karşılık bireyler lehine hak yaratıcı konularda İdare Hukuku'nda kıyasın varlığının kabul edilmesi gerekir. Hak yaratıc1 işlemlerde kıyas kişi aleyhine bir sonuç doğurmadığından hukuki güvenliğe aykırılık taşımamaktadır. Bu konuda özellikle karşılaştırmalı hukukta hem yargısal hem de bilimsel içtihatlar bu yönde görüş birliği içerisindedir. ${ }^{116}$

\section{B. Kamulaştırma Kanunu 22 ve 23. Maddenin Kıyasen Uygulanabilirliği}

Kamulaştırmasız el atma sonucu idarenin mülkiyetine geçen taşınmazı malikin geri alma hakk1 ya da idare tarafından iadesi konusunda, idarenin 22 veya 23. maddeye yapacağı kıyasın öncelikle hukukun hangi alanına girdiğinin tespiti gerekmektedir. Her ne kadar idarenin eski malike iade etme-etmeme kararı ve malikin geri alma kararı uyarınca geri verme-vermeme kararı idari işlem olsa da, 22 ve 23 . madde uyarınca çıkacak uyuşmazlıklar KK 24/2. fikra uyarınca adli yargının görevine girmektedir. Dolayısıyla özel hukuka ilişkin kurallar uygulanmaktadır. ${ }^{117}$ Buna istinaden söz konusu maddelerin kamulaştırmasız el atma sonucu idarenin mülkiyetine geçen taşınmazın eski malike iade veya geri verilmesinde yapılacak kıyasın, özel hukukta kıyas serbestisi sebebiyle, önünde bir engel bulunmamaktadır.

112 Ingo Schmidt (n 100) 139, 155.

113 Özel personel kanunları DMK'ya atıflar yapmaktadır. Bunun yanında Yükseköğretim Kanunu'nun 53/c.-8, 4483 sayılı kanuna atfı, KK'nun, kamulaştırmasız el atmalarda bedel tespitine ilişkin 8 . maddeye atfı örnek verilebilir. Bunun yanında Anayasada da atıflar bulunmaktadır. Örn. md. 28/4, 8; 33/son;133/son fikrası.

114 Danıştay IDDK, 2012/801, 24.5.2012 (Legalbank); Danıştay IDDK, 2014/2763, 23.6.2014 (Legalbank).

115 Kanunsuz suç ve ceza olmaz ilkesinin bir gereği olarak başka ceza hükümlerinin kıyasen uygulanmasına olanak bulunmamaktadır. Danıștay 1 D, 1998/357, 25.11.1998.

116 HOVG, 5 Bf 25/17, 21.08.2018; Beucamp (n 111) 86.

117 Kemal Gözler ve Gürsel Kaplan, 'İdari Eylemlerden Kaynaklanan Zararlara İlişkin Davalar Adli Yargının Görev Alanına Sokulabilir mi (HMK m.3 ve TBK, m.55/2 Hakkında Eleştiriler’ (2011) 6 (63) TAHD 36, 36. 
Diğer taraftan taşınmazın iadesi veya geri alma hakkı kapsamında verilecek karar idari işlem olduğundan İdare Hukuku kapsamında da bir engel bulunmamaktadır. Hak yaratıcı konularda kıyas imkânı bulunduğundan, kamulaştırma işlemine bağlı olarak tanınan taşınmazın eski malike resen iadesi ya da geri alma hakkı bağlamında verilmesine ilişkin hükümler kamulaştırmasız el atılan taşınmazların mülkiyetinin idareye geçmesinden sonrada kıyasen uygulanabilir. ${ }^{118}$ Danıştay kıyasın şartlarının geniş değerlendirerek taşınmazın iadesi hususunda İK'nun 11. maddesinde imar planlarında yol ve park gibi umumi hizmetlere ayrılan hazine ve özel idareye ait taşınmazların, belediye ya da il özel idarelerine bedelsiz terki ve devrinden sonra, devralan idarece kullanılış şekli yeni bir imar planıyla değiştirilerek özel mülkiyete konu olabilecek hale getirildiği takdirde, devreden idareye aynı usulle iade edeceği hükmünü, özel kişiler tarafından terk edilen taşınmazlar için de uygulanacağına hükmetmektedir. ${ }^{119}$ Söz konusu kanun hükmünün kıyasen özel mülkiyete konu olan taşınmazlarda uygulanmasının mülkiyet hakkını koruyan Anayasaya ve AİHS'ye, adalet ve hakkaniyet ilkelerine uygun olacağını belirterek yararlandırıcı işlemler bakımından kıyası kabul etmektedir.

KK 22 ve 23. maddelerin kamulaştırmasız el atmalarda uygulanmasında kıyasın şartları mevcuttur.

\section{a. Kanunun Mevcudiyeti}

Yukarıda ifade edildiği üzere, idarenin hukuka uygun davranarak kamulaştırma işlemiyle mülkiyetine geçirdiği taşınmazı, KK 22 ve 23. maddelerde yer alan koşullar oluştuğunda malike iade ya da malikin geri alma hakkı bulunmaktadır. Buna karşılık idarenin keyfi ve hukuka aykırı el attığı taşınmazlar yukarıda ifade edilen süreç sonucu idarenin mülkiyetine geçmesi durumunda eski malike iade ve geri almasını düzenleyen bir kanun hükmü bulunmamaktadır.

\section{b. Uygulanacak Hükümde Benzerlik}

Kamulaştırmada, kamu hizmetini gerçekleştirmek için kamu yararı amacıyla özel mülkiyete el atılmaktadır. Malikin rızası varsa satın alma yoluyla idarenin mülkiyetine geçebileceği gibi, malikin rızası dışında kamulaştırma kararıyla idarenin mülkiyetine geçebilir. ${ }^{120}$ Kamulaştırmasız el atmada ise kamulaştırma yapılmamasına

118 İdarenin kamulaştırmadan vazgeçmesi veya kamulaştırmanın kesinleşmesi durumunda kamulaştırmanın sonuçlarını anlaşarak ortadan kaldırma imkânı, kıyasen kamulaştırmasız el koymaya da uygulanır. Salih Şahiniz, Teoride ve Uygulamada Kamulaştırmasız El Koyma: İdarenin Özel Mülkiyetteki Taşınmazlara Hukuka Aykırı El Koyması (1. Bası, Seçkin 2006) 235 .

119 “Devletin veya bir kamu tüzel kişisinin kamu yararı amacıyla aldı̆̆ı bir taşınmazı daha sonra imar planı değiş̧ikliği ile kamu yararına kullanma amacı dışında kendi özel mülkü olarak tescil ettirmesi temel insan haklarından olan mülkiyet hakkına keyfi bir şekilde el konularak bireylerin sahip oldukları taşınmazları üzerinde özgürce tasarruf etmelerinin engellenmesi, mülkiyet haklarının ellerinden alınması hukuk devleti ilkesine aykırıdır”. Danıştay 6 D, 2015/5917, 13.10.2015.

${ }^{120}$ KK 8/7. fikraya göre satın alma veya trampa yoluyla elde edilen taşınmaz mallar kamulaştırılmış sayılır. 
rağmen taşınmazı malikin rızası olmadan, fiilen kamu hizmetine ayrılmakta ya da kamu yararına ilişkin bir ihtiyaca tahsis edilmektedir. Hem kamulaştırmada, hem de kamulaştırmasız el koymada kamu hizmetini gerçekleştirme sebebiyle taşınmaza el konulmakta, "kamu yararı" amaçlanmaktadır. Kamulaştırma sonrasında kamu yararı ortadan kalkarsa malike iade veya geri alma hakkı tanınmaktadır. Kamulaştırmasız el atma neticesinde idarenin mülkiyetine geçen taşınmaz üzerinde de kamu yararının ortadan kalkması arasında bir fark bulunmamaktadır.

Taşınmaz sahibinin rızası ile kamu yararına terk ettiği taşınmaz üzerinde dahi kamu yararının ortadan kalkması durumunda belli şartlarda mülkiyet hakkının varlığı söz konusu olmaktadır. AİHM Karaman-Türkiye davasında KK'nun 35. maddesinde yer alan "malikin muvafakati ile kamu hizmet ve tesisleri için ayrllmış bulunan yerler için eski malikler tarafindan mülkiyet iddiasında bulunamaz ve karşıllğın isteyemez" hükmüne rağmen, taşınmaz sahibinin kamu yararı için terk ettiği taşınmaz üzerinde, terk amacina uygun bir kamu hizmeti kurulmaz ve buna istinaden eski malikin iade talebine rağmen reddedilmesi durumunda, maddenin eski malikler aleyhine mülkiyet hakkı veya tazminat talebini ileri süremeyecekleri şeklinde yorumlanamayacağını, aksi takdirde kamu yararı gerekleri ile kişisel hakların korunması arasında hüküm sürmesi gereği adil dengeyi bozacağını bunun da mülkiyet hakkını ihlal edeceğini belirtmektedir. ${ }^{121}$ Diğer bir benzerlik ise idarenin taşınmazı kamulaştırma kararından sonra malikin rızası olmaması durumunda açacağı tescil davası yoluyla elde etmesi ile idarenin taşınmaza kamulaştırmasız el koyması üzerine malikin dava açması sonucunda mahkemece idare adına tescil kararı vermesi arasında bir fark bulunmamaktadır. İdarenin taşınmazı satın alma yoluyla elde etmesi durumunda da kamulaştırma yoluyla mülkiyetine geçmektedir. Dolayısıyla kıyas için öngörülen sebep ve amaç bakımından benzer nitelikte olmak şartını da bünyesinde taşımaktadır.

\section{c. Sonuç Bakımından Uygulanabilirlik}

KK'nun taşınmazın eski malike devrini öngören 22. maddesi ile malikin geri alma hakkını düzenleyen 23. maddesinde, mülkiyetin eski malike devri hüküm altına alınmaktadır. Bu maddelerin kıyasen kamulaştırmasız el atmalara uygulanmasında da eski malike devri mümkün kılacak şekilde sonuç bakımından da uygunluk taşımaktadır. Kaldı ki idarenin hukuka uygun davranmasında kişiye bu hakları kanunla tanınırken, idarenin hukuka aykırı ve keyfi davrandığı kamulaştırmasız el atmalara tanınmaması hukuk mantığı ve hukukun temel ilkeleri ile bağdaşmaz.

Kanun koyucunun bilinçli ya da bilinçsiz olarak düzenlemediği ve kanun boşluğu olan bu durumda 22 ve 23. maddeler kiyasen uygulanabilecektir. Diğer taraftan MK. 732. madde kişilere malik olmadığı taşınmazlarda dahi önalım hakkı tanırken,

121 Karaman v Turkey, App no 6489/03 (ECHR 15 January 2008); Danıştay 6 D, 2014/372, 24.01.2014 (Legalbank). 
idarenin kamulaştırmasız el attığı taşınmazları fedakârlıkta bulunmak durumunda kalan eski malik dışında üçüncü kişilere satması hukuki yorum ve mantıkla da bağdaşmamaktadır.

Bir kanun hükmünün kıyasen uygulanması durumunda, adaletin sağlanabilmesi için o kapsama giren herkese eşit uygulanmalıdır. ${ }^{122}$ Eşit davranma kıyasın şartları arasında sayılmasa da uyulması gereken anayasal bir yükümlülüktür. Kamulaştırmasız el atma neticesinde mülkiyeti idareye gecen taşınmazların iadesinde yargı ve idare bu hükmün kapsamına giren ve bu hak bağlamında taşınmazın iadesinde eşit olarak kıyas yapılmalıdır. Bir kısmında yapılması diğer bir kısmında böyle bir kıyas yapılmaması eşitliğe aykırılık teşkil eder. Kanun koyucunun bunun önüne geçebilmek amacıyla yaptığı geçici düzenlemede kamulaştırmasız el atmalar neticesi mülkiyetin idareye geçtikten sonra ihtiyacı kalmaması ya da başka bir kamu hizmetine tahsisine lüzum kalmaması durumunda eski malike iade ve geri alma hakk1 KK' da düzenlenmesi ya da en azından ilgili madde hükümlerine atıfta bulunması uygun olur.

\section{A. Bedele İliş̧kin Sorunlar}

KK 22 ve 23. maddelere göre eski malik taşınmaz bedelini faizi ile birlikte ödeyerek taşınmazını tekrar elde edebilmektedir. Uygulamada kamulaştırmasız el atma neticesinde açılan davada Asliye Hukuk Mahkemesinin kamulaştırma bedelinin tespit edilerek malike ödenmesi ve idare adına tescil kararı vermesine rağmen, idarenin bu bedeli ödemediği ve tapuda idare adına tescil işlemi yapılmadığı durumlar söz konusu olabilmektedir.

KK Geçici 6. maddesine göre; "Bu madde uyarnnca ödenecek olan bedelin tahsili sebebiyle idarelerin mal, hak ve alacakları haczedilemez". Bu madde idareye güvence sağladığından bedel ödeme hususunda çekingen davranabilmektedir. Dolayısıyla kesinleşmiş yargı kararına istinaden başlatılan icra takibine rağmen aradan uzun yıllar geçse de idarenin taşınmaz bedelini mal sahiplerine ödemediği durumlar söz konusu olabilmektedir. Ancak bu hüküm idareyi borcundan kurtarmamakta ve dava tarihinden itibaren kanuni faiz işlemektedir. Bedelin ödenmemesi adil yargılama ve mülkiyet hakkının ihlali olarak kabul edilmektedir. Bu konuda Anaysa Mahkemesi ve Yargıtay kararları istikrar kazanmıştır. Örnek bir olayda kesinleşen mahkeme kararına istinaden alacaklının idareden taşınmaz bedelinin ödenmesi talebi üzerine Belediye 5018 sayılı Kamu Mali Yönetimi ve Kontrol Kanunu'nun 34. maddesi gereği ödeme yapılmak üzere sıraya alındığını bildirmiş ancak bedel ödenmemiş̧tir. Yapılan bireysel başvuru üzerine Anayasa Mahkemesi;

"Mahkemece hükmedilen taşınmaz bedelinin ödenmesindeki normal olmayan gecikmeler, paranın değer kaybetmesi göz önünde tutulduğunda, taşınmazına el

122 Reinhold Zippelius, Rechtsphilosophie (4. Bas1, C.H. Beck 2003) 275 ff. 
konulan kişileri belirsizlik içinde bırakarak maddi kayıplara neden olabilir. Hatta mahkemece faize hükmedilse dahi bu faiz miktarının, maddi zararların tamamın karşılama imkânı olmayabilir (bkz. Akkuş / Türkiye, B.No:19263/92, 9/7/1997, § 29).

52. Ancak hukuka aykır olarak bireyin mülkiyet hakkına müdahale eden idarenin, kesinleşen mahkeme kararlarıyla hükmedilen alacakları veya tazminatları ödememekte israr etmesi halinde, adil yargllanma hakkinin kapsamında mahkemeye erişim hakkı ihlal edilmiş olur. Anılan düzenleme, kesinleşen mahkeme kararlarıyla hükmedilen alacak veya tazminatları ödememe sebebi olamaz.

70. Ancak idarelerin, mal, hak ve alacaklarının haczedilememesi kuralının arkasına sığınarak mahkeme kararıyla hükmedilen ve kesinleşen kamulaştırmasız el atılan taşınmaz bedelini ödemekten imtina etmeleri, kamu yararı ile kişi hakları arasındaki dengeyi kişilerin zararına olacak şekilde bozabilir. Bu durum, taşınmazına el konulduğu halde, Mahkemece hükmedilen taşınmazının bedeli ödenmeyen kişi yönünden mülkiyet hakkınin ihlali niteliğinde kabul edilir."

Kaldı ki yeni tarihli Yargıtay kararlarına göre 1983 yılından sonraki kamulaştırmasız el atmadan kaynaklanan tazminatlara ilişkin ilamların infazında borçlunun gayrimenkul, menkul, hak ve alacaklarında haciz yasağı bulunmamaktadır. ${ }^{124}$ Dolayısıyla bunlar üzerinde haciz yapılabilir.

KK'nun Geçici 6/8. fikrası idarenin, mahkeme kararı gereğince nakdi ödeme yerine 3. fikradaki uzlaşma yollarını da teklif edebilmektedir. Uzlaşma idareye ait taşınmazın trampası, idareye ait taşınmaz üzerinde sınırlı ayni hak tanınması veya imar mevzuatı çerçevesinde başka bir yerde imar hakkı kullandırılması suretiyle veya bunların mümkün olmaması hâlinde nakdi bedel üzerinden yapılabilir. Bu fikraya istinaden idarenin bedeli ödememesi ve taşınmaza ihtiyacının da bulunmaması sebebiyle uzlaşma sağlayarak iadesinin önünde bir engel bulunmamaktadır.

İdare kesinleşen mahkeme kararına rağmen taşınmazın bedelini, sahibine ödememişse ve taşınmaza ihtiyacı kalmamışsa, mal sahiplerine iade etmesi ya da eski mal sahibinin taşınmazı geri alma hakkı kapsamında bedeli zaten ödemediğinden, idarenin bedeli faiziyle birlikte talep etmesi mümkün değildir. Bedel dışında devir masraflarını mal sahiplerinden alarak iade etmesi hakkaniyete de uygun olacaktır. Kaldı ki kamulaştırılan malın idare tarafindan kullanılmaması idareye (kamulaştırma) bedeli oranında zarar etmesine ve ayrıca taşınmazın hiçbir işe yaramadan atıl durumda kalmasına sebebiyet vermektedir. ${ }^{125}$

\footnotetext{
123 Anayasa Mahkemesi, Birinci Bölüm Kenan Yıldırım ve Turan Yıldırım kararı, B. No: 2013/711, 03.04.2014

124 Yargitay 12 HD, 2019/4845, 20.03.2019 (Legalbank).

125 Yargitay HGK, 2007/849, 14.11.2007 (Legalbank).
} 


\section{Sonuç}

İdare tarafindan mülkiyet hakkına müdahale, ancak Anayasa, AİHS ve Kanunun öngördüğü şekilde gerçekleşebilir. Taşınmazlara el atma usulü Kamulaştırma ve İmar Kanunu'nda öngörülmüş ve bir kamu hizmetinin ifası için kamu yararı amacıyla bir idari kararla gerçekleşeceği açıkça düzenlenmiş̧ir. KK uyarınca taşınmaz bedel karşıllı̆ında iktisap edilebilirken, İK bedelsiz iktisaba da cevaz vermektedir.

İdarenin hiçbir karara dayanmadan özel mülkiyette bulunan bir taşınmaza mal sahibinin rızası olmadan, kamu yararı gerekçesiyle olsa dahi, el koyması hukuka aykırılık teşkil eder. Ancak idare tarafindan "kamu hizmeti ve kamu yararı" gerekçesine dayanarak hukuka aykırı el atılan özel mülkiyetteki taşınmazların, idarenin mülkiyetinde kalmak şartıyla bedelinin ödenmesi, kanuni düzenlemelere konu olmuştur. Bu düzenlemeler daha çok idarenin hukuka aykırı el koymalarını af niteliğinde olup, bu soruna kamu lehine çözüm üretmeye yöneliktir. Bu nedenle idareyi cesaretlendirici bu tarz düzenlemelerin olağan hale gelmemesi gerekmektedir.

İdarenin taşınmazlara hukuka aykırı bir şekilde fiilen el koymasının yanında bir idari işleme dayanarak hukuken el koyması da söz konusu olabilmektedir. Fiilen el koymayla birlikte kamulaştırmasız el atma gerçekleşmektedir. Buna karşılık hukuki el koymada imar planlarının uygulanmasına yönelik beş yıllık imar programı süresinde, idarenin mülkiyetine geçmesine yönelik kamulaştırma ya da diğer uygulamalar yapılmaması durumunda mülkiyet hakkı kısitlanmakta ve idarenin bu hareketsizliği sebebiyle el atma hukuka aykırı hale gelmektedir.

Mülkiyetin idarede kalarak bedelin ödenmesini öngören kanuni çözümler belli zaman aralığında idare tarafindan el atılan taşınmazlara ilişkin olsa da bu zaman dilimi dışında kamulaştırmasız el atmalarda taşınmaz sahiplerinin mülkiyet hakkının tanıdığı bütün imkânları kullanarak hukuki başvuru yollarına müracaat hakkı bulunmaktadır. KK'nun eski mal sahiplerine tanıdığ 1 iade ve mal sahibinin geri alma hakkı kamulaştırmasız el atmalar için kanunla tanınmamıştır. Bu nedenle uygulamada sorunlar ortaya çıkmaktadır.

Kanunda bir hüküm bulunmaması sebebiyle kamulaştırmasız el atma neticesinde verilecek tescil kararından sonra eski mal sahibine iade veya geri alma hakkının kullanılması hususunda KK'daki ilgili maddelerin kıyasen uygulanması özel hukuk ve idare hukukunda kıyas yasağı-serbestisi açısından ele aldığımızda bir engel bulunamamaktadır. KK' da bu konularda çıkacak uyuşmazlıklar için adli yargının görevli kılınması sebebiyle, özel hukuktaki kıyas ilke ve şartları çerçevesinde yapılacaktır. Kıyas yapılması için aranan, kanunda mevcut bir hükmün bulunmaması, uygulanacak benzer bir hüküm olması ve sonuç bakımından uygulanabilirliği şartları mevcuttur. Dolayısıyla kamulaştırmasız el atma neticesinde mahkemelerce verilen tapuda idare adına tescil kararından ya da başka bir şekilde mülkiyetine geçmesinden 
sonra, idarenin söz konusu taşınmazlara ihtiyacı kalmaması, kamu yararının ortadan kalkması, başka bir kamu hizmetine tahsise lüzum olmaması durumunda eski malike iade edilmesi ya da geri alma hakkının kullanılması konusunda KK 22 ve 23. maddelerinin kıyas yoluyla uygulaması gerekmektedir. Hatta mülkiyet hakkını koruyan Anayasa ve AİHS'in yanında, adalet ve hakkaniyet ilkeleri gereğince kıyası gerekli kılmaktadır. İdarenin söz konusu taşınmazları başkasına satmasında olduğu gibi, aksine bir durum hem söz konusu düzenleme ve ilkelere aykırılık teşkil edecek, hem de mülkiyet hakkının tanıdığı kişisel hakkın ve adil dengenin ihlaline sebebiyet verecektir. Kaldı ki idarenin hukuka uyun kararı neticesinde mülkiyetine geçen taşınmazda eski malikin sahip olduğu hakların, mülkiyet hakkının keyfi ve hukuka aykırı bir şekilde ihlal edilerek, sonrasında kanuna uygun hale getirilerek mülkiyetin elde edilmesinde söz konusu hakların tanınmaması, Hukuk Devleti ile bağdaşmaz.

Hakem Değerlendirmesi: Diş bağımsız.

Çıkar Çatışması: Yazar çıkar çatışması bildirmemiştir.

Finansal Destek: Yazar bu çalışma için finansal destek almadığını beyan etmiştir.

Peer-review: Externally peer-reviewed.

Conflict of Interest: The author has no conflict of interest to declare.

Grant Support: The author declared that this study has received no financial support. 


\section{Bibliyografya/Bibliography}

Akyılmaz B, İdari Usul İlkeleri Işı̆̆̆ıda İdari İşlemin Yapılış Usulü (1. Bası, Yetkin 2000).

Akyılmaz B, Sezginer M ve Kaya C, Türk İdare Hukuku (12. Bası, Savaş 2020).

Antalya G, Hukuk Teorisi ve Hukuk Metodolojisi, C.1 (1. Bas1, Seçkin 2019).

Ayhan F, 'Kamulaştırma Kanunu'nun Geçici 6. Maddesi ve Türk Hukukunda "dolayısıyla kamulaştırma” Uygulaması Üzerine Bir Deneme'(2011) 69 (1-2) İÜHFM 1125-1148.

Bilge N, Hukuk Başlangıcı (22. Bası, Turhan 2007).

Çuvalcı A, Kamulaştırma Kanunundan Doğan Bedel Ve Tescil Davaları (1. Bası, Seçkin 2019). Ankara 2019.

Detterbeck S, Allgemeines Verwaltungsrecht mit Verwaltungsprozessrecht (4. Bas1, C.H. Beck 2006).

Erdoğmuş T, Salt İdari Eylem Karşısında İdarenin Sorumluluğu (1. Bas1, XII Levha 2021).

Gölcüklü M A, Kamulaştırma Kanunu Şerhi: Fiili ve Hukuki El Atma Davaları (2. Bası, Seçkin 2018). Gözler K ve Kaplan G, 'İdari Eylemelerden Kaynaklanan Zararlara İlişkin Davalar Adli Yargının Görev Alanına Sokulabilir mi (HMK m.3 ve TBK, m.55/2 Hakkında Eleştiriler' (2011) 6 (63) TAHD 36-41.

Gözler K, Hukukun Genel Teorisine Giriş, Hukuk Normlarının Geçerliliği Ve Yorumu Sorunu (1 Bas1, US-A 1998).

Gözler K, Kamu Hukukçuları Platformu, Anayasa Hukukunda Yorum ve Norm somutlaşması, Tebliğler (TBB 2012).

Gözler Kemal, İdare Hukuku, C. 2 (. Bas1, Ekin 2019).

Gözübüyük A Ş ve Tan T, İdare Hukuku C. 2, İdari Yargılama Hukuku (2. Bas1, Turhan 2006).

Gusy C, 'Richterrecht und Grundgesetz’(1992) 45 (11) DÖV 461- 470.

Günday M, İdare Hukuku (10. Bas1, İmaj 2011).

Güriz A, Hukuk Başlangıcı (19. Bas1, Siyasal 2019).

Jarass H D ve Pieroth B, Grundesetz für die Bundesrepublick Deutschland, Kommentar (5. Bas1, C.H. Beck 2000).

Karaca E, 'Kamulaştırmasız El Koymanın Unsurları ve Kamulaştırmasız El Koyamaya Karşı Yargısal Başvuru Yolları' 2018 (137) TBBD 273- 309.

Kaya C, Kararlarından Hareketle Kamu Yararı Kavramına Danıştay’ın Bakışı, (1. Bası, On İki Levha Yayınları 2011).

Kayıhan İ ve Donay S, Karşılaştırmalı ve Uygulamalı Ceza Hukuku, Genel Kısım 1 (1. Bası, Beta 2005).

Kayıhan Ş, Hukukun Temel Kavramları (7. Bası, Seçkin 2017).

Kırca Ç, 'Örtülü (Gizli Boşluk Ve bu Boşluğun Doldurulması Yöntemi Olarak Amaca Uygun Sinırlama (Teleologische Reduktion)’ (2001) 50 (1) AÜHFD 91-119.

Kulaklı E, 'İdari Yargının Görevli Olduğu Kamulaştırmasız El Atma Davalarında Taşınmazın Tescili Sorunu'(2015) 2 (1) İstanbul Medipol ÜHFD 185-198.

Kutlu Gürsel M, Kamulaştırma Hukuku (3. Bası, Seçkin 2019).

Maurer H, Allgemeines Verwaltungsrecht, (14. Bas1, C.H. Beck 2004).

Müller M, Rechtsschutz gegen Verwaltungsrealakte, in: Tschannen Pierre (Hrsg.), Neue Bundesrechtspflege, Auswirkungen der Totalrevision auf den kantonalen und eidgenössischen Rechtsschutz (BTJP 2006). 
Özel S, ‘Anayasa Mahkemesi ve Kamulaştırmasız El Atmanın Yasallaştırılması Girişimleri’ (2015) 13 (154) LHD 61-144.

Sachs M, $\S 44 V w V f G$, in: Stelkens/Bonk/Sachs (Hrsg.), VwVfG Kommentar (6. Bas1, C.H. Beck 2001).

Sancakdar O, 'AİHM'in Gayrımenkul Mülkiyeti ve İmar Hukuku Uyuşmazlıklarına Yaklaşımından Kesitler Ve Karar Örnekleri’ İzmir BD (2019), 84 (3) 511-558.

Şahin C, Acele Kamulaştırma (1. Bası, XII Levha 2018).

Şahiniz S, Teoride ve Uygulamada Kamulaştırmasız El Koyma: Ídarenin Özel Mülkiyetteki Taşınmazlara Hukuka Aykırı El Koyması (1. Bası, Seçkin 2006).

Tarhanlı İ B, ‘Uyuşmazlık Mahkemesi Kararları Işığında Kamulaştırmasız El Atma’ (1990) 11 (1-3) İHID 41-47.

Thorsten I S, 'Die Analogie im Verwaltungsrecht' (2006) 97 (2) VerwArch 139-164.

Topakkaya A, Hukuk Hermeneutiği, Hukukta Anlama ve Yorumlama Sanatı (1. Bas1, Adalet 2019).

Yalçınduran T, '6745 Sayılı Kanun İle Hukuki El Koymalara Dair Yapılan Değişiklikler İle Hukuki Ve Fiili El Koymalara Uygulanacak Hükümler' (2017), 66 (2), AÜHFD 491- 515.

Yıldırım R, 'İdareye Taşınmaz Mal Kazandıran Bedelsiz Terk, Devir ve Temlikler' (2016) 11 (2) Karatay ÜHF 13-23.

Yıldırım T, ‘İmar Planı Yoluyla Kamulaştırmasız El Atma' (2011) 7 (81-82) Bahçeşehir ÜHFKHHD 184-199.

Yılmazoğlu Y E ve Duman Ö, 'Acele Kamulaştırmanın Mülkiyet Hakkı Bakımından Yol Açtı̆̆ Meseleler: Anayasa Mahkemesi'nin “Ali Ekber Akyol Ve Diğerleri” İle "Ali Hıdır Akyol Ve Diğerleri” Kararlarının Analizi’ (2018) 6 (11) UMD 513- 583.

Yüzbaşıŏlu N, '2001 Anayasa Değişiklikleri Üzerinde Bir Değerlendirme' Yıldızhan Yaylaya Armağan (Galatasaray Üniversitesi Yayınları no: 4, 2003) 587-604.

Zippelius R, Rechtsphilosophie (4. Bas1, C.H. Beck 2003). 
